NBER WORKING PAPER SERIES

\title{
INEFFECTIVE CONTROLS ON CAPITAL INFLOWS UNDER SOPHISTICATED FINANCIAL MARKETS: BRAZIL IN THE NINETIES
}

\author{
Bernardo S. de M. Carvalho \\ Márcio G.P. Garcia \\ Working Paper 12283 \\ http://www.nber.org/papers/w12283
}
NATIONAL BUREAU OF ECONOMIC RESEARCH
1050 Massachusetts Avenue
Cambridge, MA 02138
May 2006

Carvalho: E-mail bscarvalho@gaveainvest.com.br. Garcia: Departamento de Economia - PUC-Rio, Rua Marques de São Vicente, 225, Rio de Janeiro, RJ, 22453- 900, Brazil, mgarcia@econ.puc-rio.br. The views expressed herein are those of the author(s) and do not necessarily reflect the views of the National Bureau of Economic Research.

(C2006 by Bernardo S. de M. Carvalho and Márcio G.P. Garcia. All rights reserved. Short sections of text, not to exceed two paragraphs, may be quoted without explicit permission provided that full credit, including (C) notice, is given to the source. 
Ineffective Controls on Capital Inflows Under Sophisticated Financial Markets: Brazil in the Nineties

Bernardo S. de M. Carvalho and Márcio G.P. Garcia

NBER Working Paper No. 12283

May 2006

JEL No. E44, F32, F34, F36, G15

\begin{abstract}
$\underline{\text { ABSTRACT }}$
We analyze the Brazilian experience in the 1990s to assess the effectiveness of controls on capital inflows in restricting financial inflows and changing their composition towards long term flows. Econometric exercises (VARs) showed that controls on capital inflows were effective in deterring financial inflows for only a brief period, from two to six months. The hypothesis to explain the ineffectiveness of the controls is that financial institutions performed several operations aimed at avoiding capital controls. To check this hypothesis, we conducted interviews with market players. We collected several examples of the financial strategies engineered to avoid the capital controls and invest in the Brazilian fixed income market. The main conclusion is that controls on capital inflows, while they may be desirable, are of very limited effectiveness under sophisticated financial markets.

Márcio Gomes Pinto Garcia

Department of Economics

Pontifical Catholic University

Rua Marques de Sao Vicente, 225

Gavea - Rio de Janeiro - RJ

22451-041 BRASIL

mgarcia@econ.puc-rio.br
\end{abstract}




\section{INTRODUCTION}

International economic literature has given substantial attention to the destabilizing effects of financial globalization, a process that became particularly strong since industrial countries liberalized their capital accounts in the 1970s and 1980s. Subsequently, in the 1990s, emerging markets (EMs) followed suit.

Among the diverse proposals for reforming the "international financial architecture" aimed at creating a more stable environment is taxation of international capital flows ${ }^{3}$. The idea, in fact, has been around since Keynes [1936] suggested that taxing financial transactions could strengthen the importance investors place on longterm fundamentals in pricing assets. Decades later, the idea gained popularity in the academic community through the Tobin Tax proposal (Tobin [1978]).

Much of the recent literature has defended imposing controls on capital inflow, as Chile did during the 1990s. The objective would be to minimize the impact on EMs of capital flows instability and to reduce these countries' vulnerability to financial crises $^{4}$. The proposals defend, in general, what we could call ex ante capital controls, i.e., restrictions that are defined prior to funds entering the country, thereby respecting the contracts. This type of control differs from those the literature has called controls on capital outflows, which are generally imposed during a financial crisis, typically after, or ex post, the entry of capital, and can thus be viewed as breaching contracts with foreign investors who have then already invested resources in the country. Ex ante capital controls usually try to deter capital inflows, but could conceivably be also imposed to restrict capital outflows.

Here, we address the effects of ex ante capital controls. In contrast to ex post controls, ex ante controls should not jeopardize the emerging market country's reputation, since they are included in contracts with foreign investors prior to their investing. We will analyze the effectiveness of inflow controls to limit short-term capital and modify the composition of financial inflows.

Several authors have suggested controls on capital inflows as an economic policy measure for managing excessive capital inflows into EMs. In periods of greater liquidity and low international risk aversion, it is common for substantial financial flows to move into Latin America and Asia. The year 2004 was a classic example: "dollar weakness", or expectations of greater depreciation of the U.S. dollar due to forecasts that the U.S. current account deficit had to be reversed ${ }^{5}$, together with low base interest rates in developed countries. Both factors led to substantial capital inflows into EMs. As a result, Colombia adopted capital inflow controls to avoid accelerated appreciation of its currency, and many countries, including Brazil, Russia, China, Japan, and other Asian countries, rapidly accumulated international reserves so as to manage the abundant inflow of foreign currency. In this context, discussion surrounding controls on capital inflow has gained considerable steam among economists.

The central goal of establishing capital controls is containing the inflow of shortterm capital. Short-term capital flows are considered more volatile and fungible and thus more closely related to excessive exchange rate volatility and to sudden reversals of external financing which lead to harmful real results. Many articles actually argue

\footnotetext{
${ }^{3}$ Rogoff [1999], Eichengreen[1999], Stiglitz[1999] and Fischer[2002] are excellent references on the diverse proposals for reforming the international financial system.

${ }^{4}$ See Stiglitz [1999], Ito and Portes [1998], Eichengreen [1999], and Fischer [2002].

5 Obstfeld and Rogoff [2000], Obstfeld and Rogoff [2004], Roubini [2004], Blanchard and Giavazzi [2005] are good references for discussion of the expected weakening of the US Dollar as a result of the country's record current account deficits.
} 
that portfolio investments tend to be less stable than, for example, direct investment, because financial assets can be sold more easily than real assets can be liquidated. ${ }^{6}$ Moreover, today's international financial scenario includes Hedge Funds, many of which are seeking immediate gains. As of August, 2005, it was estimated that there was around US\$ 1.5 trillion in the hands of these financial institutions. ${ }^{7}$ This, together with more sophisticated information technology, has made capital flows extremely fungible. Capital controls would also avoid excessive exchange rate appreciation and allow the central bank to regain control of monetary policy. ${ }^{8}$

The economic literature is therefore brimming with debate about how to manage excessive capital inflow in an exceptionally volatile global financial environment. Volatile capital accounts and consequent volatile exchange rates (except in the case of fixed exchange rates) influence decisions on investing in physical capital, since investors face greater uncertainty and higher costs on currency hedge operations, thereby affecting potential GDP. In light of this, a few authors have suggested adopting capital inflow controls and/or accumulating international reserves as a way of handling heavy inflow of foreign currency and reducing the threat of sudden stops.

Forbes [2003a] concludes that liberalization of capital accounts around the world did in fact intensify global financial instability, but the correlation between capital controls and limiting vulnerability to confidence crises is not particularly close or direct, as many writers have argued. Forbes [2003b] also observes that the controls diminish microeconomic efficiency, for example by increasing the cost of capital of small and medium-sized companies, which have less access to financial markets. Large companies have access to the international financial market and to ways of circumventing restrictions on external financing, so that they are less impacted by capital controls.

Glick and Hutchison [2004] explore the effectiveness of controls in avoiding or delaying financial crises. Based on an analysis of panel data from 69 countries, they conclude that restricting capital did not bring the desired results. Eichengreen and Leblang [2002], analyzing a panel of 47 countries, examine whether capital controls were effective in reducing the impact of financial crises in the real economy. They conclude that the controls impaired economic growth in periods of stability, but that they eased the effect on the country's product once the crisis unfolded. However, these papers do not separate the effects of capital controls on inflows from those on outflows.

This article narrows the analysis of the effectiveness of capital controls. We explore whether controls on capital inflows are effective in limiting and selecting capital flows. Thus, we analyze whether this type of control effectively meets its primary objective. The issue concerns positive economics and not normative economics. Naturally, if we were to show that the controls are not effective-as we will indeed claim it has been the case in Brazil-whether the controls are desirable or not would become irrelevant for policy purposes.

In general, the literature addresses short-term capital controls without considering the capacity of international investors to avoid the restrictions imposed. The general rule has been to implicitly assume that de jure imposition of capital controls is the same as their de facto application. However, developed and sophisticated financial markets present diverse substitute assets that may be used to engineer financial transactions that avoid part or all of the costs incurred by the capital controls. Garcia and Barcinski [1998] and Garcia and Valpassos [2000] focus on this issue for Brazil.

\footnotetext{
6 See Dixit and Pyndick [1994], Frankel and Rose [1996], and Dornbusch [1998].

${ }^{7}$ Chan, Getmansky, Haas and Lo [2006].

8 Cowan and De Gregorio [2005] say that the goals of Chilean capital controls were to "... stem net inflows, avoid a large appreciation and keep control of monetary policy."
} 
They indicate the ineffectiveness of inflow controls in reducing the inflow of capital seeking the high returns of Brazilian public debt between 1994 and 1996. Papers addressing the case of Chile, such as those of Simone and Sorsa [1999], Edwards, Valdés and De Gregorio [2000] and Cowan and De Gregorio [2005], also stress that circumvention of capital controls may have limited its effectiveness in changing the composition of the financial inflows.

In this paper, we conduct econometric exercises-based on an analysis of impulse response functions inspired by the VAR analysis of Cardoso and Goldfajn [1997] - that show that the capital controls were only effective in restricting financial capital inflows in Brazil in the 1990s for two to six months. Our updated results corroborate those from previous papers.

The novelty of this paper is in the methodology aimed at explaining why capital controls lost de facto effectiveness. This paper's main contribution is its focus on the limiting effects that the avoidance of capital controls practiced by financial market players had on the effectiveness of controls on capital inflows. Based on interviews with financial market players active during the analyzed period, we exemplify methods (financial strategies) that could have been used to avoid capital control laws in Brazil during the 1990s.

The article is divided as follows: after this introduction, Section II briefly discusses capital control legislation; Section III presents a VAR analysis aimed at measuring the effectiveness of the capital controls in reducing short-term financial inflows; Section IV reports cases of avoidance of capital restrictions that explain how capital controls were rendered almost ineffective; and Section V contains the conclusion.

\section{CAPITAL CONTROLS IN BRAZIL}

Brazil's exchange rate and capital controls legislation is highly complex and confusing, mixing normative rulings from the period of the Vargas administration in the thirties with modern resolutions. Exchange rate regulation is still considered an impediment to capital flows due to its complexity, and its reform is one of the most important issues for ensuring continued development of the Brazilian financial market ${ }^{9}$.

The legal framework for exchange rate transactions and foreign capital establishes the following key points: foreign exchange must be converted into the national currency, the real (BRL), which is the only legal tender in the country; resources secured offshore or those addressed in Law 4131/62 ${ }^{10}$ must be brought back into the country; export revenues earned abroad must be brought back into the country (surrender requirements); and private exchange rate transactions are prohibited, meaning the Central Bank holds a monopoly on exchange rate transactions. In summary, the legal framework is aimed at keeping all possible foreign exchange in the country.

In March of 2005, the National Monetary Council (CMN) simplified currency legislation in an effort to streamline and reduce the costs of capital flow with Brazil. It did not, however, change the legal framework or any laws, but rather published new CMN resolutions. These measures are part of a process of liberalization and correction of the asymmetries of legislation governing currency transactions with other countries, which the Central Bank undertook some years ago. Among the principal measures, we

\footnotetext{
${ }^{9}$ Reforms of exchange rate regulations are also needed to support the increased amount of international trade, but we will not touch on this important issue here.

${ }^{10}$ Law 4131 of 1962 regulates foreign capital in the country.
} 
note: merging of the Free Rate (MCTL) and Floating Rate (MCTF) Exchange Markets, since Brazil still legally had a system with multiple exchange rates; authorization to make direct offshore remittances without use of the CC-5 accounts ${ }^{11}$; a longer period for bringing foreign currency revenues from exports back into the country; and authorization of Foreign Forward Currency Agreements (ACC) for exportation of services.

The following economic papers address Brazil's tangled exchange rate and foreign capital legislation: Franco [1990], Cardoso and Goldfajn [1997], Garcia and Barcinski [1998], Garcia and Valpassos [2000], Arida [2003], Franco and Pinho-Neto [2004], and Goldfajn and Minella [2005]. The annual Bulletins of Brazil's Central Bank also address the issue, discussing exchange rate policy and summarizing the legal proceedings of the institution, the $\mathrm{CMN}$, and the Ministry of Finance during the course of the year. In this section, we present an overview of this legislation to offer a context for discussing the effectiveness of controls on capital inflows.

Much of prevailing exchange rate legislation was established over 60 years ago. Only exchange rate rules for foreign direct investments remained stable, as Franco and Pinho-Neto [2004] emphasize.

In 1931, Decree 20.451/31 conceded the monopoly of exchange rate transactions to the Banco do Brasil and established what was called the "centralization of foreign exchange transactions." Decree 25.258/33 consolidated the exchange rate policy and defined "illicit exchange rate transactions" as those conducted outside the official monopoly, or subsequently by establishments the monopoly holder authorized for such. Today this holder is the Central Bank of Brazil. This Decree 25.258/33 is still in effect and stipulates that "understating the value of export cover or increasing prices of imported goods to obtain undue cover is punishable by law." Until today this 1933 ruling requires exporters to convert their offshore revenues into domestic currency (surrender requirements) and penalizes overpricing of imports and underpricing of exports. The maximum term for bringing export revenues back to Brazil has changed numerous times. As noted above, in March of 2005 the term was extended to 210 days after shipping, as compared to the previous 180 days (Resolution 3266/05).

Rules for foreign capital in Brazil were consolidated under Law 4.131 of 1962, which remains in effect today. As Franco and Pinho-Neto [2004] noted, "subsequent laws smoothed some of the more prominent edges of Law 4.131/62," but government authorities still have substantial discretionary power to impose or reverse restrictive measures for exchange rate flows.

In general, current legislation still clearly allows the CMN to set measures for controlling foreign capital flows. One example is the set of restrictive measures that may be enacted in the event of "urgent needs of foreign exchange," as defined in Article 28 of Law $4.131 / 62^{12}$ : simple administrative decisions can establish controls on capital

11 "CC-5" accounts were maintained by those not residing in Brazil and were created by the Central Bank's Directive No. 5 in 1969. These resources had free access to the MCTF (Floating Rate Exchange Market) to purchase foreign currency and send it offshore. It also authorized remittance from others through the account. "CC-5" accounts were the main vehicle for both residents and non-residents to access foreign markets.

${ }^{12}$ Law 4.131/62 Art. 28

"Art. $28-$ Any time there is extreme imparity in the balance of payments, or serious grounds for assessing there will be, the National Monetary Council may impose restrictions, for a limited period of time, on the entry and exit of revenues in foreign currency, and to this end, grant the Banco do Brasil a complete or partial monopoly on exchange rate transactions. 
outflows and foreign exchange centralization. This attests to the uncertainties surrounding Brazil's legislation, signaled by Bacha, Arida and Lara-Rezende [2005] as one of the major determinants of the country's very high sovereign risk.

Until the 1980s, exchange rate legislation focused primarily on foreign currency outflows in an environment of restricted capital account's transactions. It only authorized the sending of foreign capital whose ingress into the country was documented. The remittance of profits and dividends were taxed. With the 1980 debt crisis, international capital stopped flowing toward Latin America, so that only the egress and not the ingress of foreign currency had to be contained.

Beginning in 1987, and especially after the 1994 institution of the Real Plan, the Brazilian government adopted a directive for liberalizing the current and capital accounts. In the early 1990s, inflows increased, and as the economy stabilized in the second half of the decade and Brazil returned to the foreign debt market, the pace of capital inflows accelerated considerably. Chart 1 demonstrates the evolution of the inflow of foreign portfolio investments.

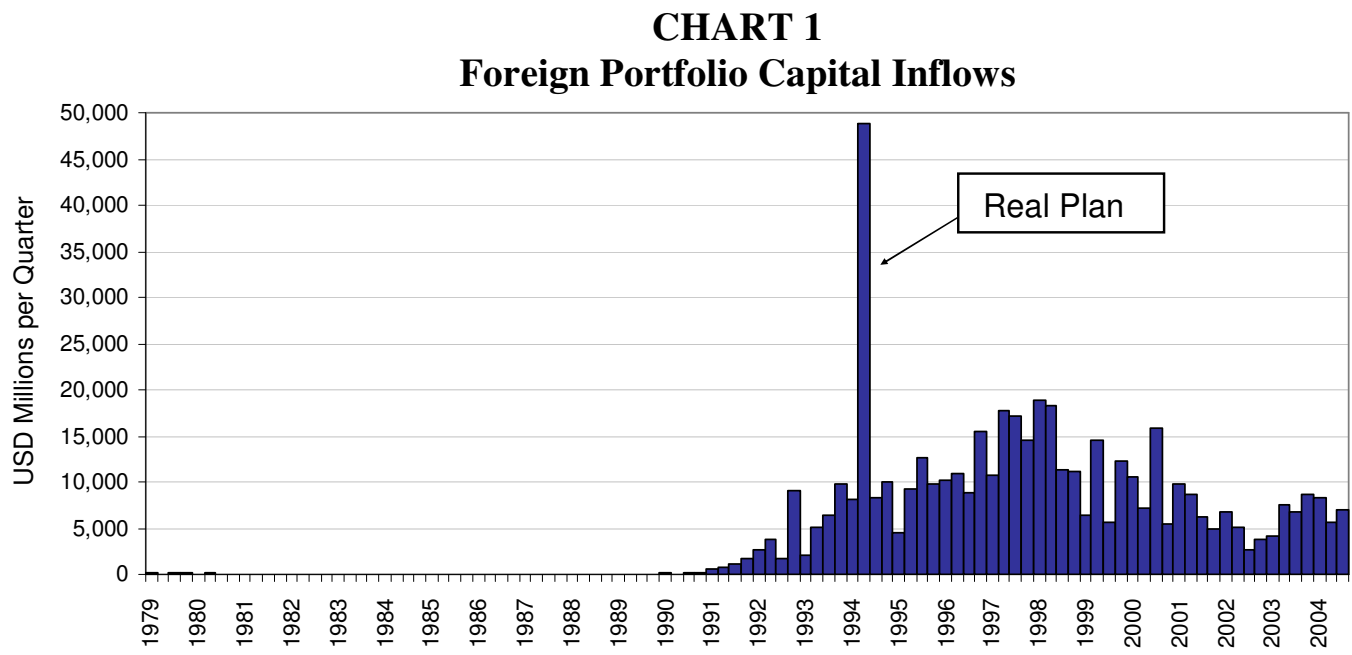

Source: Central Bank of Brazil

Financial flows to Brazil gained momentum following renegotiation of the country's external debt in 1994, under the Brady Plan model applied in several Latin American countries, and with the success of the stabilization provided by the Real Plan.

$\S 1$ - In the case provided for in this article, remittances of capital return are prohibited, and remittance of their profits limited to a maximum of $10 \%$ (ten percent) per year, related to capital and reinvestments registered in the currency of the country of origin, in the terms set forth in Articles 3 and 4 of this Law. $\$ 2$-Revenues exceeding the percentage fixed by the National Monetary Council, as set forth in the preceding paragraph, must be listed with the Central Bank of Brazil, which, if the restriction provided for in this article is extended for over one fiscal year, may authorize the remittance, in the subsequent fiscal year, of the remaining amounts, if the profits made do not reach that limit.

$\$ 3$ - In the same cases of this article, the National Monetary Council may limit remittance of funds for paying "royalties" and technical, administrative or similar support up to the annual cumulative maximum of $5 \%$ (five percent) of the company's gross earnings. $\$ 4-$ Also in the cases of this article, the National Monetary Council is authorized to issue rulings limiting currency spending on "International Travel."

$\S 5$ - There are no restrictions, however, on remittances of interest or amortization quotas contained in duly registered loan agreements." 
The increase of capital inflows that began at the end of 1991 generated problems for managing the country's macro economy. Abundant inflows of foreign capital triggered appreciation and excessive exchange rate volatility and/or accumulation of international reserves, and a consequent increase of the public debt due to sterilized intervention. Additionally, most of the capital that entered at that time was for shortterm investments given the very high real interest rates prevailing in Brazil. This type of investment, termed carry-trade, is usually reversed very quickly at the first sign of depreciation of the receiving country's currency. As such, it enhances the probability of a sudden stop, and also sparks greater economic volatility.

In fact, the 1990s oscillated between periods of excessive inflow, such as between 1992 and 1995 and then between 1996 and the middle of 1997, and periods of shortage of foreign capital in times of international crises (crisis in Mexico which hit Brazil in 1995, Asian crisis in 1997, and crises in Russia and Brazil in 1998 and 1999, respectively). In periods of excessive inflows, controls were placed on capital inflows in an effort to limit short-term capital and alleviate the effects of too much foreign currency, causing appreciation or, to prevent it, forcing fiscally expensive sterilized interventions. In periods of shortage, controls were lifted in an attempt to attract capital to finance the Brazilian balance of payments, since current account deficit grew from $3 \%$ of GDP in 1995 to $5 \%$ in 1999. Capital controls were, then, endogenous to external financing conditions and to monetary policy, as shown by Cardoso and Goldfajn [1997].

In 1987, incentives for foreign portfolio investments in the country were provided by the Central Bank of Brazil's Resolution 1289, which exempts foreign investors from income tax on capital gains in Brazil. The Resolution's Annex IV was the preferred channel by investors to make tax exempt investments in Brazil. However, in August 1993, to contain excess inflows of short-term capital aimed at profiting from the very high interest rates prevailing in Brazil, the CMN prohibited using the "Annex IV" mechanism to invest in government bonds. The purpose was actually to prohibit fixed income investing in general, authorizing only investing in the capital market. But numerous loopholes in the legislation opened the door for fixed income investments through this mechanism, as the following section shows. Fixed income investments then officially had to enter the country via specific funds that were subject to an IOF tax of $5 \%$ to $9 \% .^{13}$ This was one of the main measures for controlling capital inflows in the $1990 \mathrm{~s}$, but the market managed to bypass it in numerous ways and reap gains from the high short-term interest rates without paying the IOF.

In 1999, Resolution 1289 was revoked by Resolution 2689, and the IOF tax was removed for fixed income investments. ${ }^{14}$ Currently, most capital flows are registered in the Central Bank's electronic registration system, the RDE, ${ }^{15}$ including most of those

\footnotetext{
${ }^{13}$ In November of 1993, the Foreign Capital Fixed Income Fund was established, charging a 5\% IOF tax (IOF stands for Tax on Financial Transactions, which is a tax that can be easily and quickly imposed or changed by the Ministry of Finance, not having to wait to the following fiscal year to take effect). In October 1994, the IOF was raised to 9\%. In March of 1995, due to the Tequila Effect (Mexican Crisis), the IOF was lowered to 5\%, and then raised again in August of that year to 7\%. In April of 1997, it was lowered from 7\% to 2\%, and in March of 1999 to 0.5\%. In August of 1999 this IOF was eliminated, but the capital from the investment write-off had to be invested on the BOVESPA for at least one day, or be held without remuneration for 15 days. For investments of less than 90 days, a 5\% IOF tax is levied even today (May 2006).

${ }^{14}$ Traders in Brazil still refer to the investment mechanism of the prevailing Resolution 2689 as "Annex IV."

${ }^{15}$ The RDE is divided into IED, ROF and Portfolio registration. RDE-IED: Foreign Direct Investment; RDE-ROF: Financial Transaction Registration: financing and importation, commercial leasing, rental and freight, services and technology, currency loans, advance payment of exports, and asset investments; RDE-Portfolio: portfolio investing.
} 
governed by Resolution 2689. The process allows for closer monitoring and greater transparency of financial flows. Only very short term (less than 90 days) fixed income investments are charged the 5\% IOF tax. There are also rules in Annex V of Resolution 2689 for Depositary Receipts (DR), when shares of Brazilian companies are issued abroad with counterpart shares in Brazil. This movement is not registered in the RDE. Finally, until March of 2005, the account for non-residents (CC-5) was still in place. It was not declared on the RDE and served as a vehicle for foreign capital to enter the country.

Controls on capital inflows, rather, ex ante controls on capital inflows, in the 1990s focused largely on limiting short term inflows, restricting fixed income investments and short term loans. Export revenues were also strictly regulated. As we have seen, since 1933 exporters have been subject to surrender requirements within a specified period, today 210 days. Forward foreign currency agreements (ACC), a mechanism to provide credit for exports are also restricted even today to a maximum 360 days prior to shipping.

Based on the methodology of Cardoso and Goldfajn [1997], we updated the index of controls on capital inflows and outflows through 2004. The original article had constructed the index through 1996, and we updated them for this paper. The methodology is simple: add +1 to the base index if the control restricts the analyzed type of flow (inflow or outflow), and -1 if it liberalizes it. The methodology applies to the indices of the controls on both capital inflows and capital outflows. ${ }^{16}$

CHART 2

Capital Inflows Controls Index (jan/83 = 100)

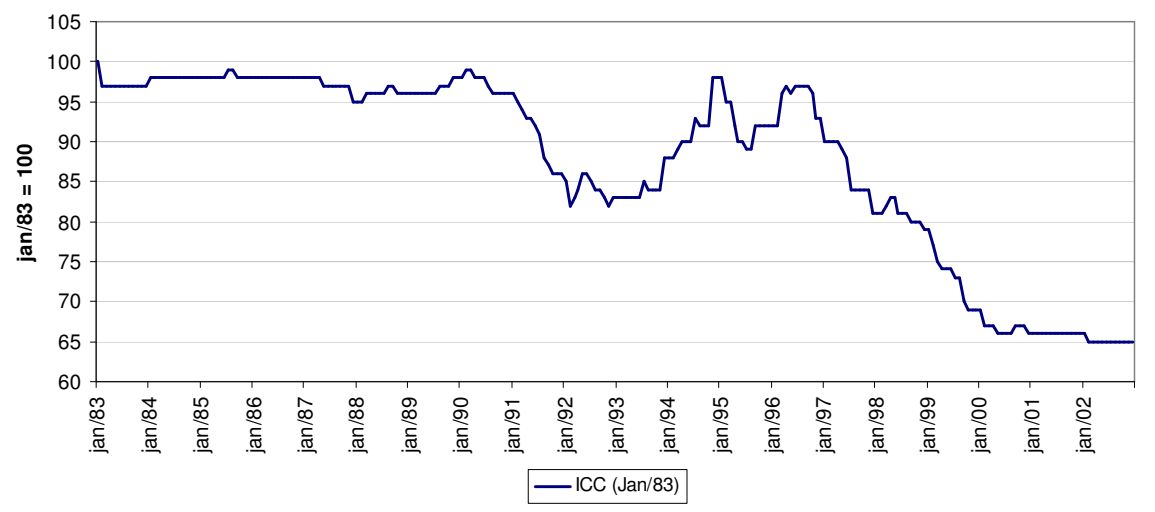

${ }^{16}$ However simple, this methodology has the drawback of considering that all measures had similar effects on capital flows, which is clearly a problem. Nevertheless, we believe that the indices rightly capture the major trends. 


\section{CHART 3 \\ Capital Outflows Controls Index (jan/83 = 100)}

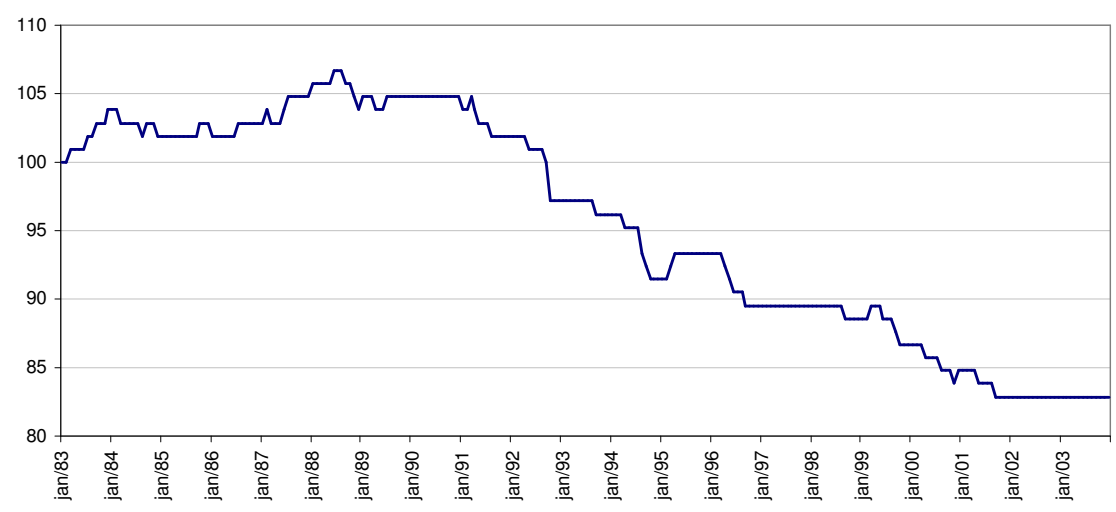

Chart 3 clearly shows that since the early 1990s a trend toward liberalizing outflows has prevailed. Yet, Chart 2 shows that only beginning in 1997 was there an unequivocal trend toward liberalizing capital inflows. This is because between 1997 and 1999 there were a crisis in Asia, a crisis in Russia, and a currency crisis in Brazil, so there was no need for adopting controls on capital inflows. In 1999, Brazil floated its currency and defined a clear directive for liberalizing the capital account in order to reap the benefits of external savings. One example was in August of 1999, when the IOF tax was lifted for fixed income foreign investments of over 90 days that were previously under Annex IV.

In the next section we provide econometric evidence of the very limited effectiveness of the controls on capital inflows imposed by Brazilian authorities in the 1990s.

\section{III - A VAR ANALYSIS OF THE EFFECTIVENESS OF INFLOW CONTROLS IN DETERRING CAPITAL INFLOWS}

In this section we conduct an econometric analysis using a vector autoregression model to examine whether controls on capital inflows in Brazil have been effective in reducing the inflow of financial capital.

The methodology is based on the articles of Cardoso and Goldfajn [1997] and Edwards, Valdés and De Gregório [2000], which used the VAR model to analyze the effectiveness of capital controls in Brazil and in Chile, respectively.

Cardoso and Goldfajn [1997] examined the effect of controls on capital inflows in the period from 1983 to 1995 , concluding that the impact of inflow controls on the total net inflow was temporary (around six months). They used VAR estimation, because they showed that the controls are endogenous to the dynamic of the capital inflows. Here, we apply a similar procedure to the period between 1995 and 2001, using, however, different capital inflow measures and other endogenous variables. We chose not to extend the sample beyond 2001 given there were very few changes to legislation on capital inflows between then and 2004, so there is little to be inferred from the period about the effect of controls on capital flows ${ }^{17}$.

\footnotetext{
${ }^{17}$ See the chart with the Capital Inflow Controls Index in Section IV.
} 
Edwards, Valdés and De Gregório [2000] estimated a VAR to analyze simultaneously the effectiveness of controls in containing capital inflows and in altering the term of foreign investments. They used as one of the endogenous variables a Power Index for monitoring the effect of control circumvention on the effectiveness of restrictions on short term capital. We did not build a similar index from Brazil because we felt that, with the available data, its accuracy and reliability would not be sufficient. ${ }^{18}$ Edwards, Valdés and De Gregório [2000] concluded that Chile's control on capital inflows did not effectively reduce the total capital inflow, but it did increase the percentage of long term flows. In other words, the controls were effective in reducing short term capital, but the total inflow remained stable as more long term capital entered the country. However, they argued that the result may be distorted by short term capital investments that were declared as long term. They could not guarantee that the control power index was able to isolate the effect of this type of avoidance.

In this section we estimate three VARs. They differ in the variable that measures capital inflows. Charts 4 and 5 show the different series we used on a monthly base and accumulated in 12 months.

\section{CHART 4}

Financial Capital Flows Measures

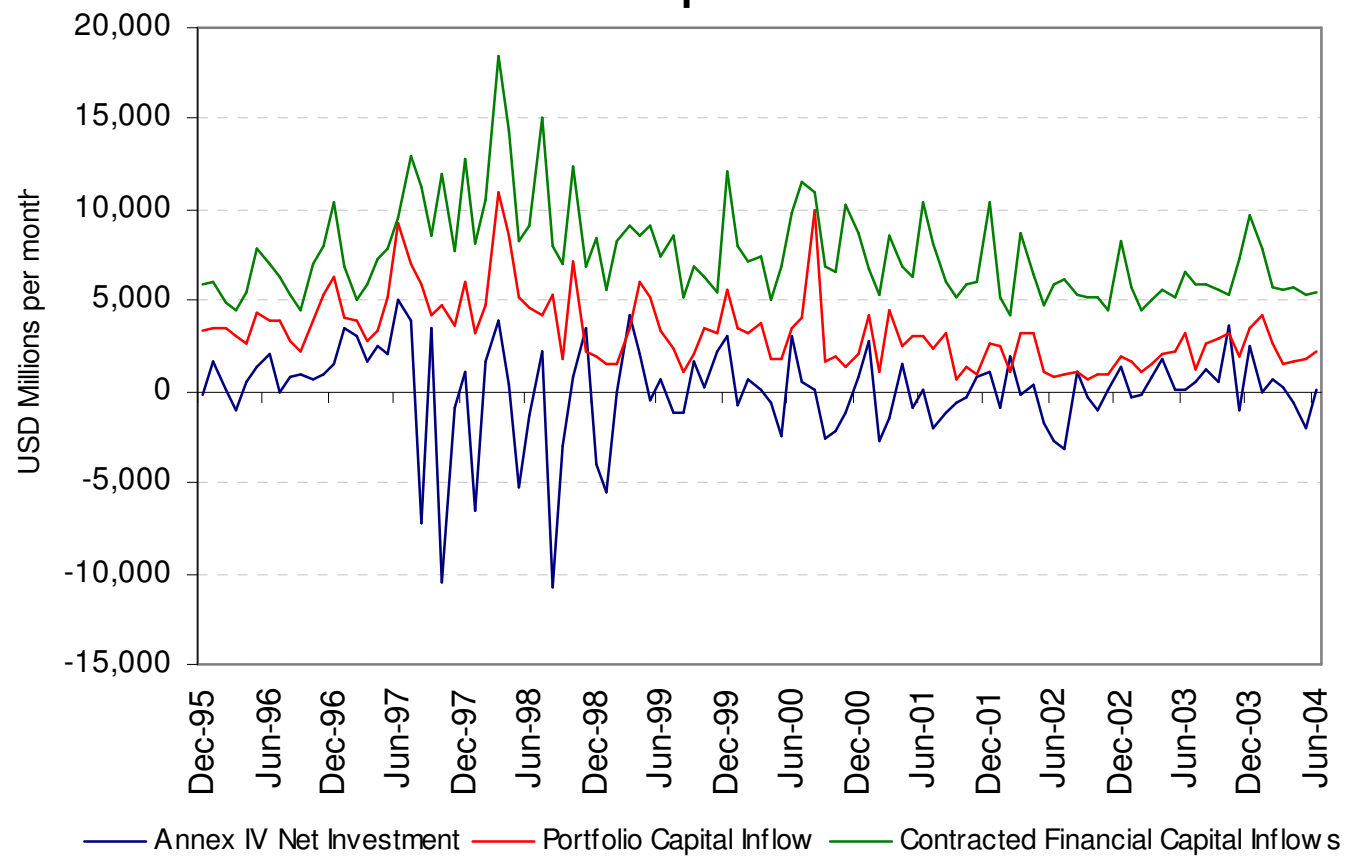

Source: Central Bank of Brazil and CVM

\footnotetext{
${ }^{18}$ The index is formed by attributing rates of 0 to 1 for each new restrictive measure. When the restriction was applied, the measure received a rating of 1 . With the passing of time, if the restriction was circumvented, the rating moved closer to 0, where the measure was assessed as having lost all effectiveness. Establishing a similar index for Brazil was a complex task, because it involved a large number of exchange rate of measures and because the Brazilian financial market was more developed than the Chilean.
} 
CHART 5

Financial Capital Flows Measures

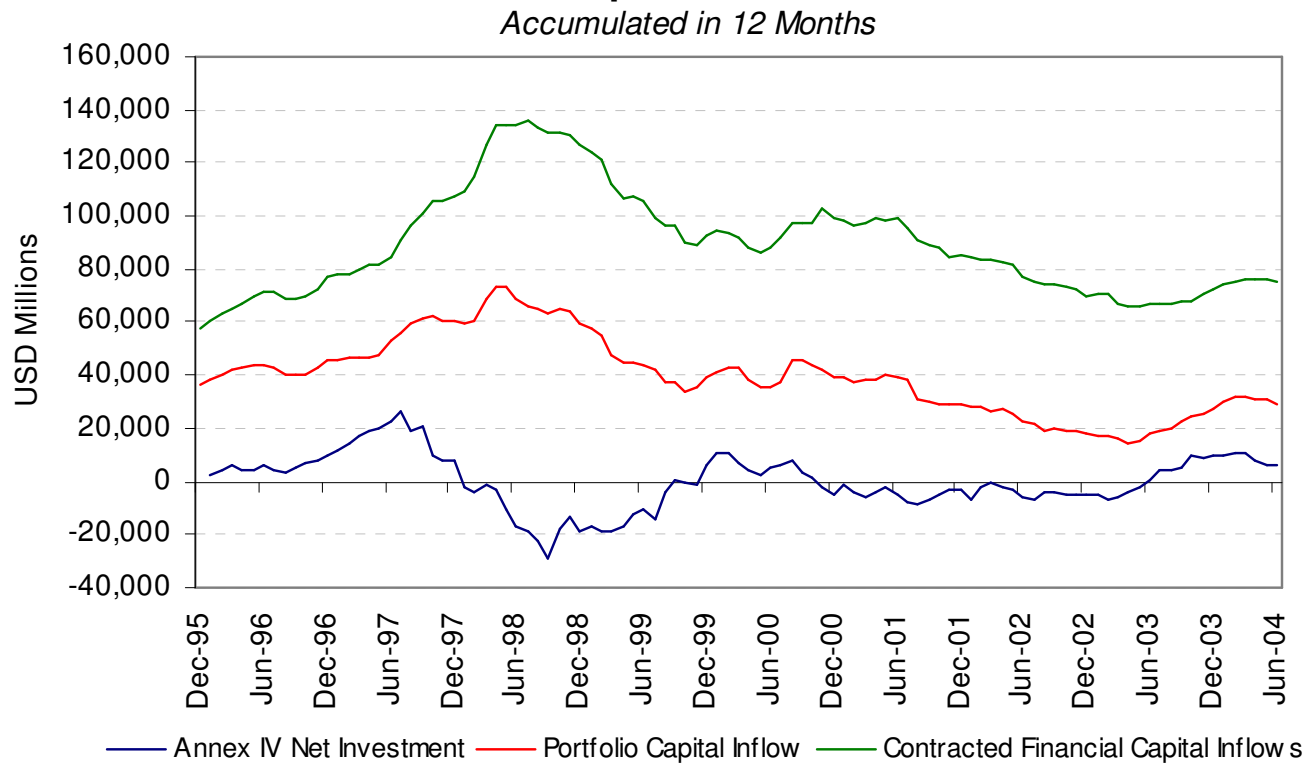

Source: Central Bank of Brazil and CVM

The capital inflow measure of the first VAR is the Brazilian Central Bank series on the inflow of portfolio investments in Brazil. The inflow measure of the second VAR is the contracted exchange rate inflows for financial transactions. The measure for the third is net investments through the Annex IV channel. The use of three different measures of capital inflows is aimed at providing robustness to our analysis. All of the VARs have the same endogenous variables: the deviation of the effective real exchange rate to its equilibrium level, the covered interest parity differential, the measure of capital inflows, and the logarithmic difference of the index of capital inflow controls. The exogenous variables varied in the VAR specifications. The number of lags for each VAR was chosen based on the Akaike and the Schwartz information criteria. In order to obtain the impulse response functions, we applied the Cholesky decomposition for identifying a VAR's structural form. It is essential to note that the results were robust with the several orderings of contemporaneous causality among the endogenous variables, so this possible criticism does not affect our results.

The main objective of the estimation of these VARs is to analyze the impulse response function of the capital flows to a change in capital inflow controls. The variation from the index of capital inflow restrictions presented in Section III was used as the measure of capital controls. It is important to clarify that the index's order of integration is equal to 1 , so that we had to use the first difference to obtain a stationary series. In Chart 6 below, we present the capital inflow controls variation series. From 1983 to 1995, the series was constructed, as we have already noted, on Cardoso and Goldfajn [1997], and updated for this article after 1995. 


\section{CHART 6}

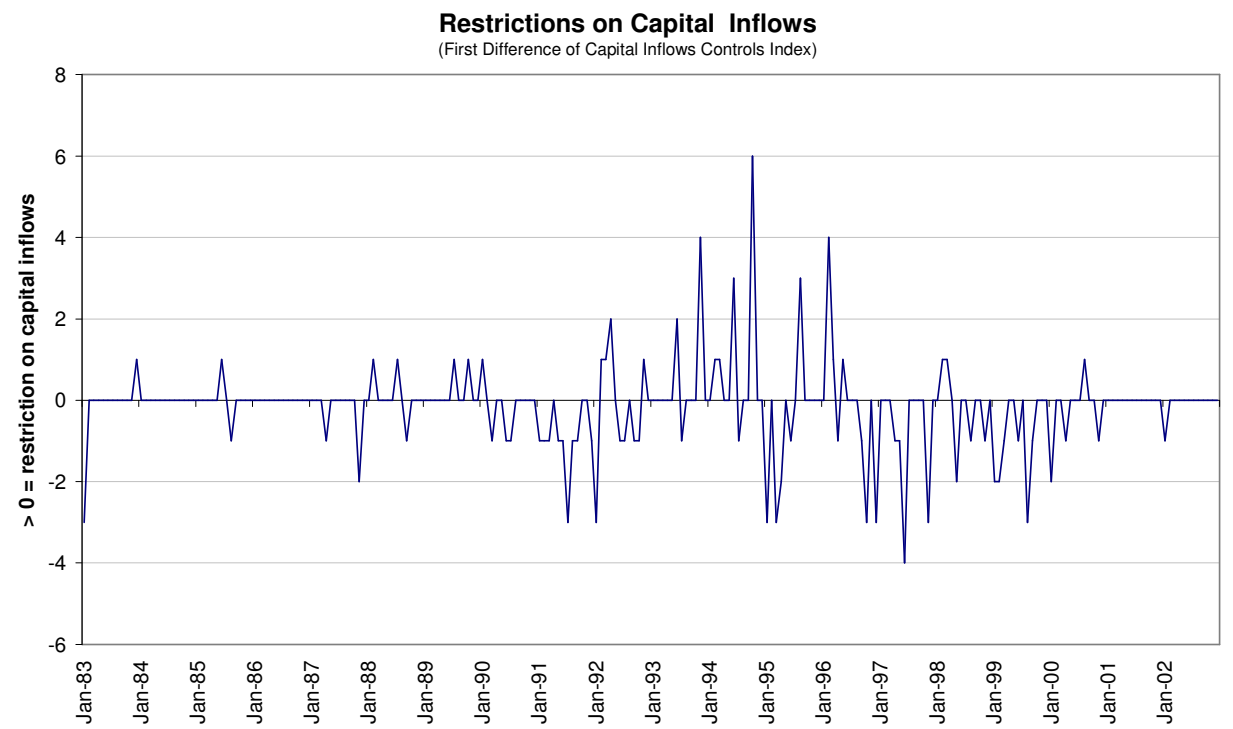

The results were as follows:

The first VAR has the following endogenous variables:

- Logarithmic variation of the equilibrium real effective interest rate (LOG(REER_DESVIO2)), which was calculated as the logarithm of the ratio between the index value of the real effective exchange rate and a series trend extracted by applying the Hodrick-Prescott filter beginning January of 1995.

- Covered interest parity differential (CIPD) in continuous capitalization, or $L O G(1+C I P D)$, where $L O G$ is the logarithm in the Neperian base.

- Logarithm of the portfolio investment inflows as a percentage of the GDP (LOG(IEC_CRED/PIB)), which is our capital flow measure in this first VAR.

- Finally, the logarithmic variation of the Index of Capital Inflow Controls (D(LOG(ICC)).

The exogenous variables used were the American one-year futures rates (LOG(1+US1Y)), which summarize the level of international liquidity; the variation of the Index of Capital Outflow Controls (D(LOG(ICC_S )), which was calculated as an exogenous variable because we considered that economic policy had lifted outflow controls independent of capital flows, as indicated by the downward trend of the ICC-O in Chart 3 of Section II; and lastly, some circumstantial dummies from the period of the Brazilian currency crisis. Dummies for other periods of financial crisis were not significant, since the effects were probably captured by the endogenous variables, especially the real exchange rate and the covered interest parity differential. The exception was the wave of speculation in 1998, when there was a large inflow of capital even with the higher sovereign risk, followed by a mass exodus after depreciation, for which a binary dummy variable was applied.

Table 2 VAR01 summarizes the output of the first VAR estimation, and Chart 7 shows the impulse response function of the portfolio investment inflows to new restrictions on capital inflows. We see that a new control measure on capital inflows initially reduces the portfolio investment inflows and peaks in the second month. However, its effectiveness diminishes rapidly, and up to around six months following its implementation, the effect on capital flows disappears. Therefore, the exercise indicates that controls on capital inflows in Brazil are temporarily effective, lasting 
around two to six months. This period would be the time required for the market to discover investment alternatives for circumventing the restriction. ${ }^{19}$

\section{TABLE 2: VAR 01 - Portfolio Investment Capital Flows}

\begin{tabular}{|c|c|c|c|c|}
\hline \multicolumn{5}{|l|}{ Vector Autoregression Estimates } \\
\hline \multicolumn{5}{|c|}{ Sample(adjusted): 1995:03 2001:01 } \\
\hline \multicolumn{5}{|c|}{ Included observations: 71 after adjusting endpoints } \\
\hline \multicolumn{5}{|c|}{ Standard errors in ( ) \& t-statistics in [ ] } \\
\hline & LOG(REER_DESVIO2) & LOG(1+CIPD) & LOG(IEC_CRED/PIB_USD) & $\mathrm{D}(\mathrm{LOG}(\mathrm{ICC}))$ \\
\hline \multirow{3}{*}{ LOG(REER_DESVIO2(-1)) } & 0.848994 & -0.063483 & -0.065995 & -0.04362 \\
\hline & -0.06995 & -0.02975 & -0.81052 & -0.02845 \\
\hline & [ 12.1367] & {$[-2.13415]$} & {$[-0.08142]$} & {$[-1.53336]$} \\
\hline \multirow[t]{3}{*}{ LOG(1+CIPD(-1)) } & 0.002434 & 0.993933 & -0.057779 & 0.148311 \\
\hline & -0.15516 & -0.06598 & -1.7978 & -0.0631 \\
\hline & [ 0.01569] & [ 15.0641] & {$[-0.03214]$} & [ 2.35048] \\
\hline \multirow[t]{3}{*}{ LOG(IEC_CRED(-1)/PIB_USD(-1)) } & -0.029375 & -0.010079 & 0.465205 & 0.004209 \\
\hline & -0.00986 & -0.00419 & -0.11421 & -0.00401 \\
\hline & {$[-2.98003]$} & {$[-2.40444]$} & [ 4.07310] & [ 1.04999] \\
\hline \multirow[t]{3}{*}{$\mathrm{D}(\operatorname{LOG}(\operatorname{ICC}(-1)))$} & -0.055859 & -0.235101 & -5.725003 & -0.001572 \\
\hline & -0.33932 & -0.14429 & -3.93165 & -0.13799 \\
\hline & {$[-0.16462]$} & {$[-1.62932]$} & {$[-1.45613]$} & {$[-0.01139]$} \\
\hline \multirow{3}{*}{ C } & 0.022708 & -0.025619 & -0.424531 & -0.007136 \\
\hline & -0.07133 & -0.03033 & -0.82644 & -0.02901 \\
\hline & [ 0.31836$]$ & {$[-0.84466]$} & {$[-0.51368]$} & {$[-0.24601]$} \\
\hline \multirow{3}{*}{ LOG(1+US1Y) } & -2.027193 & -0.088474 & -19.21475 & 0.07025 \\
\hline & -1.25812 & -0.535 & -14.5774 & -0.51163 \\
\hline & {$[-1.61129]$} & {$[-0.16537]$} & {$[-1.31812]$} & [ 0.13731$]$ \\
\hline \multirow[t]{3}{*}{ D(LOG(ICC_S(-1))) } & -1.346541 & -0.294861 & 14.68138 & -0.356286 \\
\hline & -0.89256 & -0.37955 & -10.3418 & -0.36297 \\
\hline & {$[-1.50863]$} & {$[-0.77687]$} & [ 1.41961] & {$[-0.98158]$} \\
\hline \multirow[t]{3}{*}{ DUM98_06 } & -0.022205 & -0.007393 & -0.183745 & 0.000461 \\
\hline & -0.03602 & -0.01532 & -0.41732 & -0.01465 \\
\hline & {$[-0.61651]$} & {$[-0.48273]$} & {$[-0.44030]$} & {$[0.03146]$} \\
\hline \multirow[t]{3}{*}{ DUM98_09 } & -0.017627 & 0.014355 & -1.193587 & -0.00198 \\
\hline & -0.03742 & -0.01591 & -0.43353 & -0.01522 \\
\hline & {$[-0.47110]$} & [ 0.90224$]$ & {$[-2.75317]$} & {$[-0.13015]$} \\
\hline \multirow{3}{*}{ DUM98_10 } & -0.072689 & -0.031912 & 0.784007 & -0.00372 \\
\hline & -0.04323 & -0.01838 & -0.50086 & -0.01758 \\
\hline & {$[-1.68154]$} & {$[-1.73603]$} & [ 1.56532] & {$[-0.21161]$} \\
\hline \multirow[t]{3}{*}{ DUM98_11 } & -0.033384 & -0.007341 & -1.097422 & -0.015072 \\
\hline & -0.03745 & -0.01593 & -0.43398 & -0.01523 \\
\hline & {$[-0.89131]$} & {$[-0.46092]$} & {$[-2.52874]$} & {$[-0.98951]$} \\
\hline \multirow{3}{*}{ DUM98_12 } & -0.058555 & -0.016687 & -0.69168 & 0.001728 \\
\hline & -0.03929 & -0.01671 & -0.45521 & -0.01598 \\
\hline & {$[-1.49044]$} & {$[-0.99883]$} & {$[-1.51949]$} & {$[0.10816]$} \\
\hline \multirow[t]{3}{*}{ DUM99_01 } & 0.141244 & 0.010355 & -0.428468 & -0.021543 \\
\hline & -0.03941 & -0.01676 & -0.45668 & -0.01603 \\
\hline & [ 3.58358] & {$[0.61781]$} & {$[-0.93822]$} & {$[-1.34407]$} \\
\hline & & & & \\
\hline R-squared & 0.863004 & 0.866213 & 0.404071 & 0.161514 \\
\hline Adj. R-squared & 0.834661 & 0.838533 & 0.280775 & -0.011966 \\
\hline Sum sq. resids & 0.06632 & 0.011993 & 8.903604 & 0.010968 \\
\hline S.E. equation & 0.033815 & 0.014379 & 0.391804 & 0.013751 \\
\hline F-statistic & 30.44762 & 31.29377 & 3.277248 & 0.931025 \\
\hline Log likelihood & 146.9012 & 207.6138 & -27.03869 & 210.7849 \\
\hline Akaike AIC & -3.771866 & -5.482079 & 1.12785 & -5.571405 \\
\hline Schwarz SC & -3.357572 & -5.067785 & 1.542144 & -5.157111 \\
\hline Mean dependent & -0.00975 & 0.068627 & -2.797709 & -0.004711 \\
\hline S.D. dependent & 0.083161 & 0.035785 & 0.461994 & 0.01367 \\
\hline Determinant Residual Covariance & & $2.68 \mathrm{E}-12$ & & \\
\hline Log Likelihood (d.f. adjusted) & & 542.9422 & & \\
\hline Akaike Information Criteria & & -13.82936 & & \\
\hline Schwarz Criteria & & -12.17218 & & \\
\hline
\end{tabular}

${ }^{19}$ The confidence intervals of the impulse response functions in our exercise are wide and limit the potential of our results. A similar problem occurred with the VARs of Goldfajn and Cardoso [1997] and Edwards, Valdés and De Gregório [2000]. For future research, refining of the ICC may imply narrower confidence intervals. 


\section{CHART 7}

Response of LOG(IEC_CRED/PIB_USD) to Cholesky

One S.D. D(LOG(ICC)) Innovation

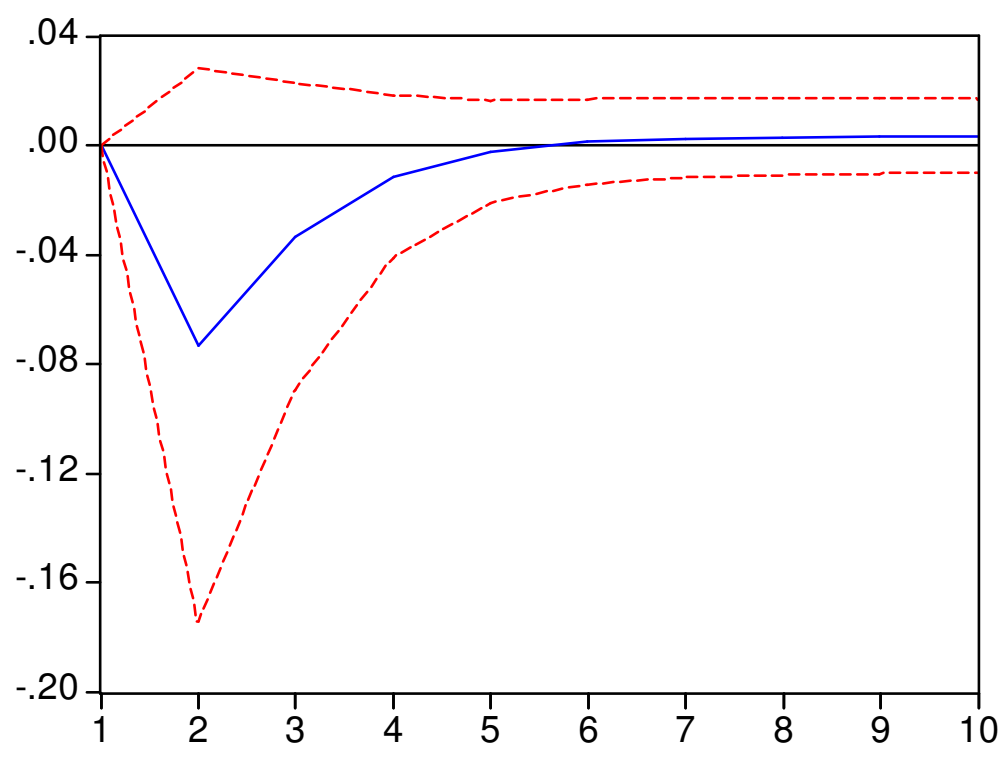

The second VAR has the same endogenous variables as the first with the exception of the capital inflow measure, which becomes the contracted exchange rate inflows for financial transactions as a percentage of the GDP (LOG(MOV_CAMBIO_FIN_COMPRA/PIB)). These are data from the Brazilian Central Bank that report the currency flows from all financial investments except for those going through the CC-5 account, that is to say, they do not include exchange rate flows from abroad and the CC-5 accounts. This series included all flows from portfolio capital, direct investments and foreign loans. Since the capital controls exempted direct investment flows, we used this data as an exogenous variable. The other exogenous variables are the same as those in the first VAR.

Chart 8 shows the impulse response function of the contracted exchange rate inflows for financial transactions to the new restrictions on capital inflows. Again, the exercise indicates that the effectiveness of inflow controls was temporary and lasted for around two to six months. Chart 9 shows the impulse response function of the capital inflow controls to an increase in capital inflows: we see that control tends to be tightened when capital inflows increase, which is consistent with the findings on endogeneity of controls indicated by Cardoso and Goldfajn [1997]. The third VAR will make even clearer the positive correlation between inflows and inflow controls. 
TABLE 3: VAR 02 - Contracted Inflow of Foreign Exchange

\begin{tabular}{|c|c|c|c|c|}
\hline \multicolumn{2}{|c|}{ Vector Autoregression Estimates } & & \\
\hline \multirow{2}{*}{\multicolumn{5}{|c|}{\begin{tabular}{|l|} 
Sam ple(adjus ted): $1995: 04$ 2001:01 \\
Inc luded obs ervations: 70 after adjus ting end po in ts
\end{tabular}}} \\
\hline & & & & \\
\hline \multicolumn{5}{|c|}{ Standard errors in () \& t-statis tic s in [ ] } \\
\hline & LOG(REER_DES VIO2) & $\operatorname{LOG}(1+C I P D)$ & $\begin{array}{c}\text { LOG(MOVCAM BIO } \\
\text { FIN_COMPR AS /P } \\
\text { IB_USD) }\end{array}$ & $D(\operatorname{LOG}(I C C))$ \\
\hline \multirow[t]{3}{*}{ LOG(REER_DESVIO2(-1)) } & 1.596 & 0.2162 & -1.297422 & -0.100528 \\
\hline & -0.12063 & -0.05501 & -0.46469 & -0.06268 \\
\hline & [ 13.2301] & {$[3.93000]$} & {$[-2.79201]$} & {$[-1.60372]$} \\
\hline \multirow[t]{3}{*}{ LOG(REER_DESVIO2(-2)) } & -0.76867 & -0.268611 & 0.956407 & 0.0504 \\
\hline & -0.12135 & -0.05534 & -0.46743 & -0.06305 \\
\hline & {$[-6.33453]$} & {$[-4.85404]$} & [ 2.04608] & [ 0.79931] \\
\hline \multirow[t]{3}{*}{$\operatorname{LOG}(1+\operatorname{CIPD}(-1))$} & -1.056099 & 0.679976 & 1.186595 & 0.169177 \\
\hline & -0.31673 & -0.14444 & -1.22005 & -0.16458 \\
\hline & {$[-3.33442]$} & [ 4.70776] & [0.97258] & [ 1.02794] \\
\hline \multirow[t]{3}{*}{$\operatorname{LOG}(1+\operatorname{CIPD}(-2))$} & 0.97209 & 0.198835 & -0.827889 & 0.068802 \\
\hline & -0.36258 & -0.16535 & -1.3967 & -0.18841 \\
\hline & [ 2.68102] & {$[1.20252]$} & {$[-0.59275]$} & {$[0.36518]$} \\
\hline \multirow{2}{*}{\multicolumn{5}{|c|}{$\begin{array}{l}\text { LOG(M OVCAM BIO_FIN_ } \\
\text { COMPRAS(-1)/PIB_USD(. }\end{array}$}} \\
\hline & & & & \\
\hline 1)) & 0.018765 & 0.002513 & 1.003293 & 0.00674 \\
\hline & -0.02638 & -0.01203 & -0.10163 & -0.01371 \\
\hline & [ 0.71122] & [ 0.20883$]$ & [9.87167] & [ 0.49163] \\
\hline $\begin{array}{l}\text { LOG(M OVCAM BIO_FIN_- } \\
\text { COMP RAS(-2)/PIB_USD }(.\end{array}$ & & & & \\
\hline 2)) & -0.035169 & -0.009047 & -0.359534 & 0.003547 \\
\hline & -0.02523 & -0.01151 & -0.09718 & -0.01311 \\
\hline & {$[-1.39402]$} & {$[-0.78636]$} & {$[-3.69954]$} & [ 0.27054$]$ \\
\hline $\mathrm{D}(\operatorname{LOG}(\operatorname{ICC}(-1)))$ & 0.059725 & -0.1086 & -2.215967 & -0.070253 \\
\hline & -0.28181 & -0.12851 & -1.08555 & -0.14643 \\
\hline & [ 0.21193$]$ & {$[-0.84505]$} & {$[-2.04133]$} & {$[-0.47976]$} \\
\hline $\mathrm{D}(\operatorname{LOG}(\operatorname{ICC}(-2)))$ & 0.008505 & 0.124223 & 0.495162 & -0.096286 \\
\hline & -0.27883 & -0.12716 & -1.07409 & -0.14489 \\
\hline & [ 0.03050$]$ & [ 0.97693] & [ 0.46101$]$ & {$[-0.66456]$} \\
\hline C & 0.014042 & -0.025425 & 0.111609 & -0.045985 \\
\hline & -0.07082 & -0.03229 & -0.27279 & -0.0368 \\
\hline & [ 0.19829$]$ & {$[-0.78729]$} & [ 0.40914$]$ & {$[-1.24965]$} \\
\hline LOG(1+US1Y) & -0.868745 & 0.149802 & -7.091789 & 0.770644 \\
\hline & -1.38204 & -0.63025 & -5.32373 & -0.71814 \\
\hline & {$[-0.62860]$} & [ 0.23768$]$ & {$[-1.33211]$} & [ 1.07311] \\
\hline LOG(FDI/PIB_USD) & 0.000618 & -0.00281 & 0.12433 & -0.001046 \\
\hline & -0.00637 & -0.00291 & -0.02456 & -0.00331 \\
\hline & [ 0.09698$]$ & {$[-0.96666]$} & [ 5.06297] & {$[-0.31565]$} \\
\hline D(LOG(ICC_S)) & -1.630759 & -0.129044 & 3.996622 & -0.129792 \\
\hline & -0.76518 & -0.34894 & -2.94752 & -0.3976 \\
\hline & {$[-2.13122]$} & {$[-0.36981]$} & [ 1 1.35593] & {$[-0.32644]$} \\
\hline DUM98_06 & -0.006115 & 0.000449 & -0.248249 & -0.002908 \\
\hline & -0.0287 & -0.01309 & -0.11056 & -0.01491 \\
\hline & {$[-0.21305]$} & [ 0.03433$]$ & {$[-2.24530]$} & {$[-0.19501]$} \\
\hline DUM98_09 & -0.010423 & 0.021473 & -0.164069 & 0.000891 \\
\hline & -0.03136 & -0.0143 & -0.12078 & -0.01629 \\
\hline & {$[-0.33243]$} & [ 1.50171$]$ & {$[-1.35836]$} & [ 0.05468$]$ \\
\hline DUM98_10 & 0.002162 & -0.006708 & -0.28825 & 0.003468 \\
\hline & -0.03334 & -0.01521 & -0.12844 & -0.01733 \\
\hline & [ 0.06485$]$ & {$[-0.44114]$} & {$[-2.24427]$} & [ 0.20015$]$ \\
\hline DUM98_11 & -0.053352 & -0.011768 & -0.125101 & -0.008403 \\
\hline & -0.02978 & $-1.36 \mathrm{E}-02$ & -0.11471 & -0.01547 \\
\hline & {$[-1.79157]$} & {$[-0.86656]$} & {$[-1.09057]$} & {$[-0.54303]$} \\
\hline DUM98_12 & -0.021103 & -0.000484 & -0.114811 & 0.003305 \\
\hline & -0.03068 & -0.01399 & -0.11818 & -0.01594 \\
\hline & {$[-0.68787]$} & {$[-0.03461]$} & {$[-0.97153]$} & [ 0.20729$]$ \\
\hline DUM99_01 & 0.172991 & 0.023576 & -0.032087 & -0.020608 \\
\hline & -0.02993 & -0.01365 & -0.1153 & -0.01555 \\
\hline & [ 5.77975] & [ 1.72729] & {$[-0.27831]$} & {$[-1.32504]$} \\
\hline R-squared & 0.925925 & 0.917272 & 0.927996 & 0.227275 \\
\hline Adj. R-squared & 0.901708 & 0.890226 & 0.904456 & -0.025346 \\
\hline Sum sq. resids & 0.035599 & 0.007403 & 0.52824 & 0.009612 \\
\hline S.E. equation & 0.026165 & 0.011932 & 0.100789 & 0.013596 \\
\hline F-s tatistic & 38.23482 & 33.91548 & 39.42249 & 0.899667 \\
\hline Log likelihood & 166.1117 & 221.0752 & 71.70878 & 211.9372 \\
\hline A kaike A IC & -4.231763 & -5.802149 & -1.534537 & -5.541062 \\
\hline Schwarz SC & -3.653578 & -5.223964 & -0.956352 & -4.962878 \\
\hline Mean dependent & -0.010592 & 0.068454 & -2.025573 & -0.004352 \\
\hline S.D. dependent & 0.083457 & 0.036013 & 0.326072 & 0.013427 \\
\hline Determinant Residual Cove & variance & $1.09 \mathrm{E}-13$ & & \\
\hline Log Likeliho od (d.f. adjuste & & 647.389 & & \\
\hline A kaik e Inform ation Criteria & & -16.43969 & & \\
\hline Schwarz Criteria & & -14.12695 & & \\
\hline
\end{tabular}

Schwarz Criteria 


\section{CHART 8}
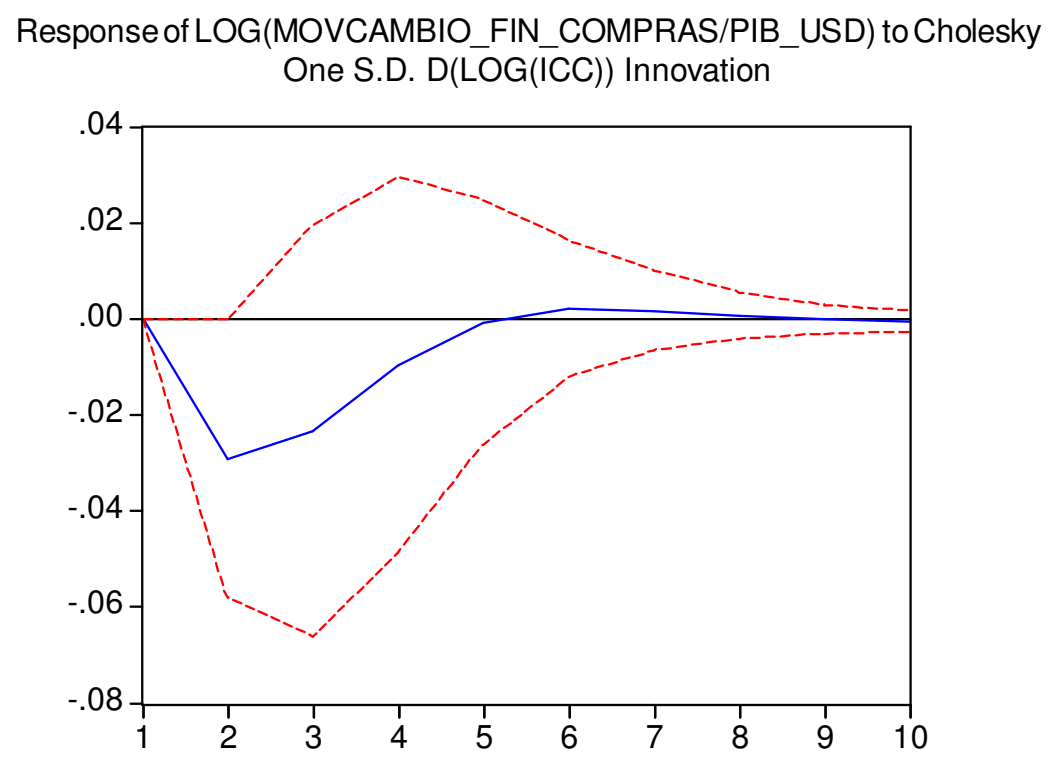

\section{CHART 9}

Response to Cholesky One S.D. Innovations \pm 2 S.E.

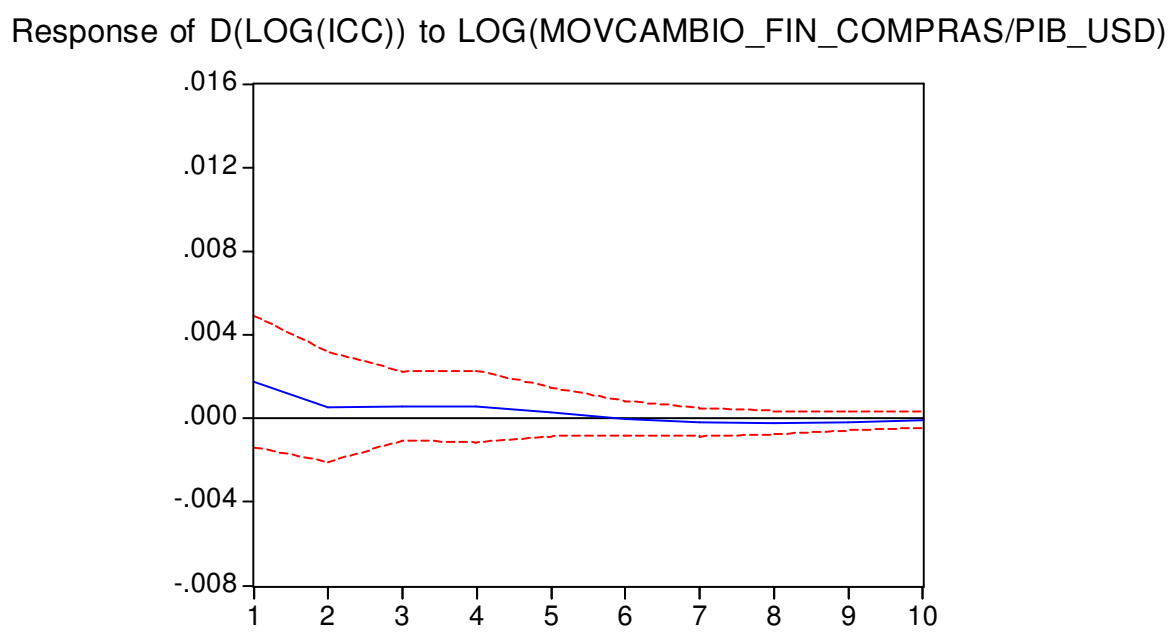

The third VAR uses net investments through Annex IV as the capital flow measure. No series for capital inflows through this channel are available, but only data on the total portfolio value under Annex IV in the country. Therefore, in this VAR we used a logarithmic difference of the Annex IV portfolio as the measure of net capital inflow. As in our other estimations, we considered capital flows as a percentage of the GDP (D(LOG(CART_ANEXO4/PIB)). The other endogenous variables were the same as those of the previous estimations. As an exogenous variable, we used only one dummy for the Brazilian currency crisis, because the other variables we adopted were not statistically significant in this exercise. 
Once again, the impulse response function of the capital flow measure to a new capital inflow control measure (Chart 10) indicated that restrictions on financial inflows were effective only temporarily. In the case of flows through Annex IV, the effect of the controls appears to be even more transitory, lasting only two to three months. Strikingly, most avoidance cases, as we saw in the previous section, continued using the Annex IV channel to invest so as to guarantee tax benefits. The impulse response function of Chart 11 shows the authorities reaction to the increase in Annex IV inflows. Greater capital inflows using this means led to tighter restrictions on capital inflows. This result shows the endogeneity of capital controls to capital inflows, consistent with the findings of Goldfajn and Cardoso [1997].

TABLE 4: VAR 03 - Capital flows through Annex IV Channel

\begin{tabular}{|c|c|c|c|c|}
\hline \multicolumn{5}{|l|}{ Vector Autoregression Estimates } \\
\hline \multicolumn{5}{|l|}{ Sample(adjusted): 1995:03 2001:01 } \\
\hline \multicolumn{5}{|c|}{ Included observations: 71 after adjusting endpoints } \\
\hline \multicolumn{5}{|c|}{ Standard errors in ( ) \& t-statistics in [ ] } \\
\hline & LOG(REER_DESVIO2) & LOG(1+CIPD) & D(LOG(CART_ANEXO4/PIB_USD)) & $\mathrm{D}(\mathrm{LOG}(\mathrm{ICC}))$ \\
\hline \multirow{3}{*}{ LOG(REER_DESVIO2(-1)) } & 0.899085 & -0.030183 & 0.423416 & -0.040701 \\
\hline & -0.06799 & -0.02438 & -0.2035 & -0.02269 \\
\hline & [ 13.2230] & {$[-1.23805]$} & [ 2.08071] & {$[-1.79397]$} \\
\hline \multirow[t]{3}{*}{ LOG(1+CIPD(-1)) } & -0.021034 & 0.987582 & 0.064443 & 0.139635 \\
\hline & -0.15871 & -0.05691 & -0.47501 & -0.05296 \\
\hline & {$[-0.13252]$} & [ 17.3541] & {$[0.13567]$} & [ 2.63670] \\
\hline \multirow[t]{3}{*}{ D(LOG(CART_ANEXO4(-1)/PIB_USD(-1))) } & -0.101546 & -0.046076 & -0.024486 & 0.027486 \\
\hline & -0.04225 & -0.01515 & -0.12645 & -0.0141 \\
\hline & {$[-2.40343]$} & {$[-3.04149]$} & {$[-0.19364]$} & [ 1.94971$]$ \\
\hline \multirow[t]{3}{*}{$\mathrm{D}(\operatorname{LOG}(\operatorname{ICC}(-1)))$} & 1.79E-05 & -0.250229 & -1.604453 & 0.00612 \\
\hline & -0.36086 & -0.12939 & -1.08001 & -0.12041 \\
\hline & [ 5.0E-05] & {$[-1.93392]$} & {$[-1.48559]$} & [ 0.05083] \\
\hline \multirow{3}{*}{ C } & -0.004639 & -0.001172 & -0.003257 & -0.013619 \\
\hline & -0.01232 & -0.00442 & -0.03686 & -0.00411 \\
\hline & {$[-0.37671]$} & {$[-0.26539]$} & {$[-0.08837]$} & {$[-3.31422]$} \\
\hline \multirow[t]{3}{*}{ DUM_BRASIL } & 0.036762 & -0.001772 & 0.028608 & -0.009482 \\
\hline & -0.01481 & -0.00531 & -0.04434 & -0.00494 \\
\hline & [ 2.48140] & {$[-0.33361]$} & [ 0.64522] & {$[-1.91825]$} \\
\hline & & & & \\
\hline R-squared & 0.796892 & 0.858981 & 0.153832 & 0.163088 \\
\hline Adj. R-squared & 0.781269 & 0.848133 & 0.088742 & 0.09871 \\
\hline F-statistic & 51.00551 & 79.1861 & 2.363378 & 2.53329 \\
\hline Determinant Residual Covariance & & $3.29 \mathrm{E}-13$ & & \\
\hline Log Likelihood (d.f. adjusted) & & 617.3627 & & \\
\hline Akaike Information Criteria & & -16.71444 & & \\
\hline Schwarz Criteria & & -15.94959 & & \\
\hline
\end{tabular}


CHART 10

Response to Cholesky One S.D. Innovations \pm 2 S.E.

Response of D(LOG(CART_ANEXO4/PIB_USD)) to D(LOG(ICC))

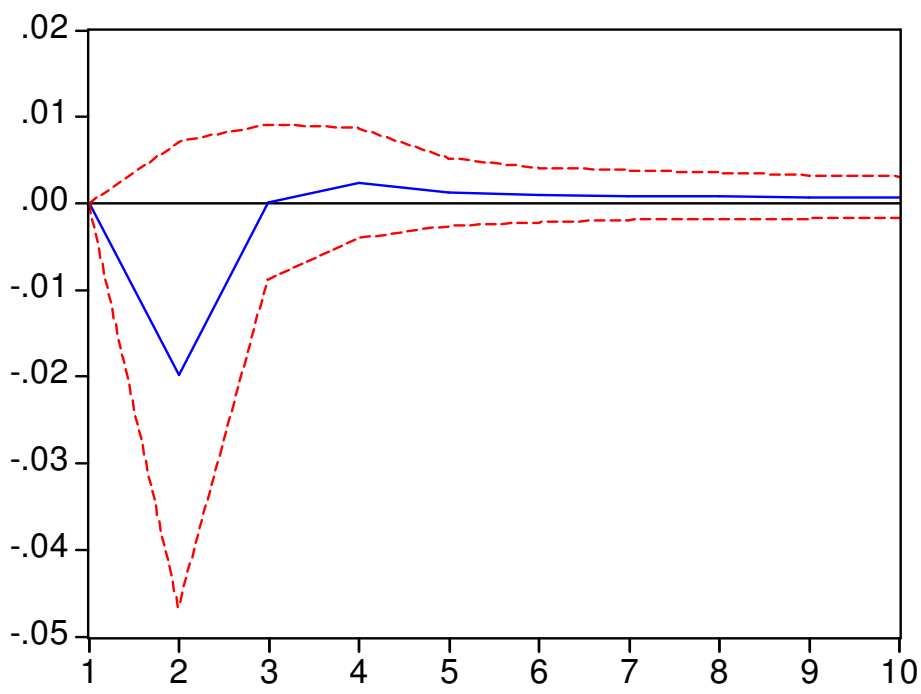

CHART 11

Response of $\mathrm{D}(\mathrm{LOG}(\mathrm{ICC}))$ to $\mathrm{D}(\mathrm{LOG}(\mathrm{CART}$ ANEXO4/PIB_USD))

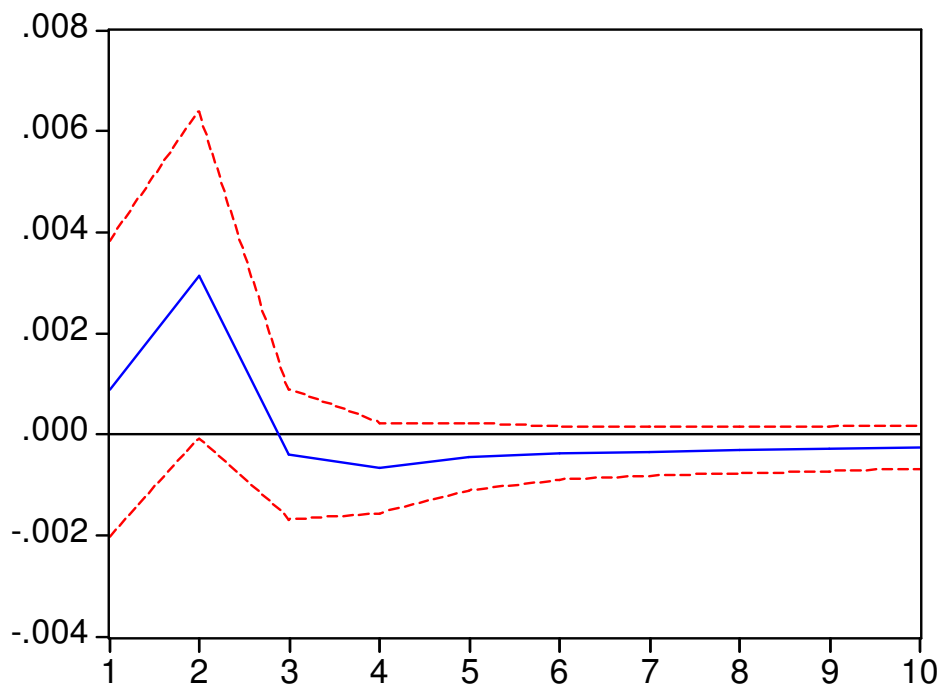

Therefore, the VAR exercises indicate that the controls on capital inflows were effective in reducing financial capital inflows only for short periods of time (two to six months). The probable cause of the limited duration of the restrictions' impact is avoidance of capital controls by the market, which continues to invest in the country without incurring in the capital controls' costs by renaming the type of investment made, or by conducting financial engineering operations. 
In the next section, we document and analyze cases of avoidance of controls on capital inflows in Brazil. Outflow controls have also been frequently avoided since the 1980s through parallel (black) exchange rate markets, but our analysis focus only on the effectiveness of controls on capital inflows.

The key point is that measures for controlling capital inflows are at best temporarily effective in containing and selecting capital inflows, since financial agents have been able to dodge them in many different ways. The lesson to be learned is that in open and developed capital markets, controls on capital inflows will probably be ineffective, because the market has many alternative assets and transactions that can capture the desired return. In the following section, we discuss cases of circumvention, and show a quantitative proof that this circumvention was at work. We do this by documenting the characteristic migration of capital inflows among Annex IV items to avoid restrictions imposed on fixed income investments and the minimum terms for offshore funding.

\section{IV - CASES OF CIRCUMVENTION OF CAPITAL INFLOW CONTROLS IN BRAZIL}

Exchange rate and capital control legislation in Brazil, as previously noted, has a tradition of being highly complex and intricate. However, the Brazilian financial market is also quite sophisticated, particularly in derivatives trading. ${ }^{20}$ The Futures and Commodities Exchange (BM\&F) of São Paulo, for example, is one of the world's largest and most active derivatives exchange, comparable to the Chicago Mercantile Exchange. Furthermore, there are extensive derivatives trading abroad with underlying Brazilian instruments. One example is New York trading of Brazilian Real/U.S. Dollar NDFs (Non-Deliverable Forwards). Derivatives allow traders to replicate financial strategies originally conceived with the underlying financial assets without the need to trade the underlying assets. For example, a box is a financial strategy involving only options that perfectly replicates a bond. The existence of derivatives makes the task of imposing capital controls much more burdensome. Since there was a well-established market for Brazilian financial instruments, including derivatives, there was, ipso facto, a variety of alternative instruments that made it possible to circumvent most capital controls.

Between 1993 and 1999, when investors were prohibited from investing in domestic Brazilian bonds through Annex IV of Resolution 1289 and charged a 5\% to 9\% IOF, there were many cases where this tax was avoided. The market found a range of methods for investing in fixed income and enjoying the tax benefits of Annex IV, at very low cost. Even today, foreign investors have ways of avoiding the tax on fixed income returns, which is higher than the tax on returns in the equity market. ${ }^{21}$

In this section (and also in the Appendix), we report numerous cases of capital controls avoidance in Brazil between 1993 and 2000, illustrating how difficult de facto application of capital controls actually is. We show that de jure imposition of restrictions in this period did not effectively contain capital inflows seeking short term, tax exempt return on fixed income, nor was it effective in extending the term of foreign investments on fixed income.

\footnotetext{
${ }^{20}$ Years of crowding out and hyperinflation created both a hypertrophy of expertise in fixed income and derivatives trading and a hypotrophy of credit granted by financial intermediaries.

${ }^{21}$ Foreign investors do not necessarily reside outside Brazil. Brazilian financial institutions generally have offices abroad designed to obtain tax benefits given to foreign capital, and also to shield against border risk, or restrictions of capital outflows.
} 
Garber [1998] addressed the issue of how offshore derivatives trading may be used to bypass domestic controls. Garcia and Barcinski [1998] and Garcia and Valpassos [2000] analyzed how avoidance of capital controls impacted their effectiveness in restricting and selecting financial flows, and they reported a few of the methods used to circumvent controls in Brazil. Simone and Sorsa [1999] concluded that the capital controls in Chile in the 1990s were only temporarily effective in restricting short term capital due to capital control circumvention. Edwards, Valdés and De Gregório [2000] concluded that Chile's capital controls effectively changed the composition of capital inflows, increasing the inflows of long term capital, but they cast doubt on the reliability of this result, which could have been distorted given that short term flows could have been labeled as long term capital flows, that is to say, effectively bypassing the country's capital controls. Forbes [2003b] noted that small and mediumsized companies in Chile were more burdened by the higher cost of capital than were large ones, because the latter had access to financial transactions on the international market that would enable them to avoid Chilean capital controls.

In this article we take a more in-depth look at capital controls avoidance practices in Brazil based on field study involving members of the financial market, who offered extensive help in collecting information about what agents did in Brazil to avoid controls on capital inflows between 1993 and 2000.

The large majority of transactions reported was legal, and merely took advantage of loopholes in the intricate exchange rate legislation. They included renaming as long term flows that were ultimately directed at short term interest rate investments. However, they were officially accounted on the balance of payments as flows destined for other purposes. For example, many flows were identified as "privatization money," which in theory would go to finance privatization programs; short term capital was disguised as foreign direct investments, which were not taxed; resources were declared as equity investments when in fact they were used to obtain fixed income return, etc. Below we will provide further details of these forms of circumvention.

The central idea is that financial agents were able to use a variety of means to bypass capital controls. The major restriction was prohibition of fixed income investments through Annex IV of Resolution 1289, which carried tax exemption rights, as we reported in the previous section. There were also numerous restrictions for minimum terms for amortizing overseas loans.

Prohibition of fixed income investments through Annex IV is the equivalent of charging an inflow tax $\tau$ that imposes a cost equal to the loss of tax benefits of investing in fixed income by other means. During the period, agents could invest in fixed income in Brazil through mutual funds specifically established for such, which were subject to an IOF tax of $5 \%$ to $9 \%$. Hence, the official $\tau$ was the IOF.

However, the de facto cost for the short term investor was the cost of circumventing the control, or $\tau^{*}$, which was certainly less than he or she would lose by not investing in fixed income through Annex IV. It follows that the actual cost incurred by the investor due to the capital control is: $\tau^{*}=\min \{\tau$, cost of circumventing inflow control\}.

Let us examine a few of the circumvention methods reported ${ }^{22}$.

\section{1) Disguising short term investments as long term, equity or trade finance}

\footnotetext{
22 The methods of bypassing capital controls were collected by the authors during interviews with Brazilian financial market players. The authors do not have information on who conducted them, or even if they actually took place.
} 


\section{CASE 1: Disguise short term capital as Foreign Direct Investment}

Foreign direct investment is considered to be the best form of capital flow to the receiving country, because it is closely associated with investing in fixed capital and the transfer of technology, and consequently with expansion of the potential GDP. It is also thought to be the least fungible, since compared to portfolio investments; it is less reversible and has a longer investment horizon. Many articles do argue that portfolio investments tend to be less stable than direct investments, because portfolio investments can be reversed more easily than real assets can be liquidated (Dixit and Pyndick [1994], Frankel and Rose [1996], Dornbusch [1998]). Thus, direct investments would be less linked to capital flight. For these reasons, capital flow regulation commonly handles direct investments differently than portfolio investments.

Notwithstanding, in an environment of capital controls, when in general the flow of direct investments wanes, market agents tend to take advantage of this loophole in exchange rate legislation to disguise their short term investments or loans as direct investments, thus bypassing the restrictions imposed. In Chile during 1996 through 1998, for example, what the Central Bank designated "Potentially Speculative Direct Investment" was also subject to encaje, that is to say, to Chile's prevailing capital controls. This was because between 1991 and 1996, when Chile required nonremunerated deposits of $10 \%$ to $30 \%$ for one year for short term investments and foreign loans, many agents were found to circumvent the restriction by (inappropriately) identifying their flows as direct investments.

In Brazil, we reviewed a transaction, likely to be used even today, designed to disguise short term capital as direct investment. The transaction has a simple structure.

At that time, investing in fixed income through Annex IV was restricted, but the channel was open for equity investments, and there were tax benefits for direct investments. Financial intermediaries could use the transaction to take advantage of these two loopholes.

The financial intermediary would create a public corporation (S.A.) and list its shares on the São Paulo Stock Exchange (BOVESPA). The company was strictly a legal entity and had no physical activity. Since the financial intermediary held all the company's shares, it could manipulate their price by arranging purchase and sell transactions with low liquidity. The price was completely artificial. The financial intermediary, having capital outside the country, would invest in the company as a foreign investor and declare this flow as direct investment. It acquired over $50 \%$ of the shares and subsequently conducted intercompany loans, considered foreign direct investments. This money, then, since the company only existed on paper, would be invested in fixed income. Returns would go to the company and be sent abroad as profit or dividends. Thus, Annex IV restrictions did not apply, even though the objective was short term returns from the high interest rates of the day.

The cost of establishing this investment in short term fixed income as a direct investment was quite low. Given the scale of capital invested, the cost of opening an S.A. corporation and listing its shares on the exchange was negligible. The agent's cost to come into the country, the aforementioned $\tau^{*}$, was fixed and much lower than the official tax. ${ }^{23}$. The financial intermediary's only expenses were for opening the

\footnotetext{
${ }^{23}$ The cost of opening a joint-stock (S.A.) company and listing its shares on the exchange, without considering programs for attracting investors (contracting banks to manage the I.P.O., press, advertising, etc.), in 2005, is between US\$20,000 and US\$100,000. If the financial intermediary used this avoidance strategy to invest US\$10 million in fixed income, it would already have saved, in the period when the
} 
corporation at the beginning of the operation. Subsequent investments had no inflow costs, meaning $\tau^{*}$ was equal to zero. The outflow costs were determined by legislation governing profit and dividend taxing of foreign companies, which have been much more advantageous for investors than taxing of portfolio investment gains. In fact, profit from foreign capital previously invested and declared in Brazil is exempt from taxes.

CASE 2: Labeling fixed income investments as equity investments

As noted above, the control on Annex IV capital inflows applied to fixed income investments. However, equity investments were not restricted, because growth of the stock market was believed to lead to greater investment capacity for the companies and contributes to the economy's expansion. Obviously, the market then sought to use the stock market to gain the coveted returns from the high Brazilian interest rates.

This Case 2 and the following Case 3 refer to avoidance of capital controls through the stock market. Case 2 involves a transaction that also takes advantage of the structure of the S.A. corporation created in Case 1.

To bypass restrictions on fixed income investments via the securities market, the financial intermediary in Case 1 could use the corporation already created. The financial intermediary would then invest in the shares of that corporation. The means used would be the Annex IV channel for investments in the BOVESPA, which were permitted at that time and still today provide tax benefits for fixed income investments. Thus, the financial intermediary invested his off-shore capital like a foreign investor in the BOVESPA by purchasing shares of the company he had opened. The amount paid for the shares was invested in fixed income and the returns remitted abroad as dividends or capital gains. Note that the financial intermediary could also manipulate the company's share prices, since it owned a $100 \%$ stake. Therefore, the investor declared equity investments while capturing the returns of fixed income.

Again the actual cost of the capital inflow in this case, the $\tau^{*}$, was only the cost of opening the S.A. corporation and listing its shares on the exchange. The cost was low compared to the financial volume invested, and it was also diluted as the investor invested, free of taxes, for several years. We can thus consider that $\tau^{*}$ was fixed and much lower than the official $\tau$.

The descriptions of Case 1 and Case 2 depict two similar methods of avoiding the restriction on gains from the short term interest rate in Brazil between 1993 and 2000. The person interviewed did not, however, wish to go into great detail, but rather offered a general overview. For the third form of circumvention, which we will elaborate below, we were able to gather more details. It also involves disguising fixed income investment flows as equity investments in order to take advantage of the tax exemption provided for in Annex IV.

\section{CASE 3: ACC and Trading Companies}

To control excessive capital inflows into Brazil, especially between 1993 and 1996, many restrictions on raising external resources were imposed. The prohibition of foreign investments in fixed income under Annex IV, for example, made it more difficult to raise funds, since loaning resources at fixed interest rates, the investor had to pay the IOF tax, because the Annex IV channel was prohibited. Moreover, minimum

IOF tax applied, at least US\$ 500,000 in IOF (5\%) expenses. The volume invested through this avoidance strategy can be much greater than US $\$ 10$ million, so that $\tau *$ could become negligible. 
terms were required for beginning loan amortization, meaning there were restrictions on short term loans. For example, in January 1993, a minimum period of 96 months was established for beginning amortization for principal and interest payments to be exempted from taxes.

At the same time, the use of Foreign Forward Currency Agreements (ACC) for exports allowed for financing of less than 360 days. The exporter could close an ACC up to one year before shipping merchandise. Theoretically, the ACC was exclusively for financing exports, and financing by this means required a physical outflow of exports associated with the contract to demonstrate that the loan had in fact been used to finance foreign trade. The market soon saw in this legislation a way to get short term loans, which additionally carried tax benefits.

The interest rate for ACC funds was normally less than the CDI, the short-termbenchmark interest rate in Brazil. This occurred because loans were less heavily taxed and because foreign investors seeking high return in Brazil offered capital at interest rates below the country's base rate due to restrictions on other investment means. Furthermore, financing foreign trade generally carries relatively low risk, since most loans are released only after the export contract has been signed, and the exports serve as collateral.

Therefore, ACCs constituted a means of getting short term loans with tax benefits and interest rates below the CDI. This was another opportunity that the Brazilian financial market players eagerly grabbed. The restriction a financial investor had to circumvent to raise funds via ACCs was demonstrating that the financing was associated with merchandise exports. An agent had a one-year period after signing an ACC to ship the financed export product.

The financial investor of course was not planning to use the resources to finance exports, so he had no product to ship. Exporters conducting foreign trade without ACCs, who did not use export financing, began selling their ACC rights to foreign investors. An ACC would then be signed to finance a specific export, but the capital would actually go to a financial investor who had purchased the exporter's right.

In this way, investors made short term investments at rates below the CDI using the ACCs, and were able to provide export documentation. Some exporters would pass this credit on to investors. In fact, until 2000 there was an underground market for export credits, that is to say, a parallel market developed for trading export documentation. An investor could simply make a loan to himself (disguised as an ACC, a loan to a Brazilian exporter) and buy this export documentation on the aforementioned market. A few banks even established trading companies, which specialized in financing foreign trade, to be able to better undertake this capital control avoidance strategy. These trading companies would contract ACC loans, then legalize the loan on the parallel market for trading ACC documentation. Since the financing cost was less than the CDI, a bank could close an ACC to finance its margin deposit on the BM\&F (interest rate derivatives) or the overnight market, and capture good returns with these standard operations. However, the money that theoretically was destined for financing foreign trade was actually invested in short term fixed income investments. This is an important example of how difficult it is to apply, de facto, capital controls.

This means of avoidance only decreased with the liberalization of fixed income investments and of the loan terms for foreign borrowing. Still today, though, financial market players consider ACCs a way to negotiate better interest rates, since the cost is less than the economy's base interest rate. Therefore, there are clear indications that this avoidance strategy would be widely adopted if new restrictions on short term capital were imposed, such as applying an IOF tax on investments provided for in Resolution 
2689. Since Brazilian exports increased remarkably in the last years, this would pose an even larger hurdle to the effectiveness of capital controls nowadays.

The capital inflow cost, the $\tau^{*}$, was the amount required to build a financial and legal structure for implementing this method of avoidance. The cost is minimal for a large, functioning bank, which additionally was compensated by using funds borrowed at less than CDI rates and invested on the overnight market. Thus, depending on the financial volume, $\tau *$ could be negative.

\section{2) Using sophisticated financial engineering (derivatives) to avoid controls}

CASE 4: Development of the international derivatives market: avoiding convertibility risks.

An increasingly common method used by international financial markets to avoid imperfect capital mobility in emerging countries (capital controls, risk of additional controls, and convertibility risks) involves foreign derivatives over-thecounter operations, most notably in New York. Foreign investors trade local assets, but without exposing themselves to the risks and costs of actually moving resources into the country.

A classic example is the trading of Real against the U.S. Dollar futures in New York, the currency Non-Deliverable Forwards (NDF). By trading this asset in New York rather than on the BM\&F in São Paulo, the foreign investor avoided all capital controls and convertibility risks.

Garber [1998] analyzes the development of the international derivatives market and its impacts on capital flows and reports diverse ways that financial intermediaries circumvented regulations on credit risk using derivatives overseas. He also points out the possible role of these off-shore operations in avoiding capital controls.

In recent years, the international derivatives market has substantially developed. One of the main engines of this transnational market is capital controls and currency convertibility risk in emerging market countries. They offer assets with greater volatility, which therefore have greater potential return, but the associated border risks hamper investing in the countries. Since the market wants to trade with them, it has developed international markets designed to avoid restrictions on capital mobility. The idea is to break down the risks involved, so that one can pick and choose which risks one wants, with the corresponding returns

CASE 5: Investing through Box operations: Strategies with options for earning fixed income returns

Initially, the Annex IV restriction only applied to fixed income investments. Other types of investments, such as in securities and derivatives, could still use this channel. The market was able to use these types of investments to profit from Brazil's short term interest rates. Cases 2 and 3 were methods of circumventing the control via the stock market. Another commonly used method was to use the derivatives market adopting options strategies that guaranteed fixed return, as we are about to see.

An operation was conducted that was known as a Box, consisting of four options, two calls and two puts, with the price on the established strike date fixed. By a non arbitrage argument, it is shown that Box return must be equal to the benchmark 
interest rate, in Brazil's case, the CDI. ${ }^{24} \mathrm{~A}$ Box is, therefore, a financial strategy involving options that is akin to a loan.

Since derivatives investments were not restricted, the market began conducting Box operations on the BM\&F and the BOVESPA to capture the return of Brazil's high base interest rates. This lasted until the Central Bank detected this market movement and subjected Box operations to the same regulations that applied to fixed income investments.

The Box strategy actually went further than avoiding foreign capital controls: it also aimed at saving on taxes levied on domestic fixed income investments. Instead of using traditional means, like investing in government bonds, many agents began conducting Box operations on the BM\&F and BOVESPA to earn fixed returns and bypass Brazil's internal revenue service's (Secretaria da Receita Federal) regulations. This form of tax avoidance ended when the Brazilian IRS (SRF) detected the loophole in the legislation and imposed the IOF tax on Box transactions as well. However, many agents were still able to disguise their Box operations.

The cost of avoiding capital controls using the Box strategy, the $\tau^{*}$, is only the cost of conducting the option transactions on an exchange. The operation itself has no more cost than traditional fixed income investments, because the difference between earnings from the buying and selling of the puts and calls is the amount invested. The cost difference may be only the brokerage fee charged by the financial agents, which is minimal in light of the volume invested. We can consider, then, that $\tau^{*}$ in this case is equal to zero. Therefore, this legislation loophole rendered the capital control completely ineffective.

CASE 6: Increased Eurobond Issues with embedded options for bypassing the minimum loan term.

In August of 1995, the government set a 5\% IOF tax on foreign loans in order to avoid excessive capital inflows. In September of the same year, the government changed the legislation in an effort to encourage long term loans, establishing a sliding IOF according to the loan term. For up to two years, the tax was 5\%; up to three years, $4 \%$; four years, $2 \%$; five years, $1 \%$; and six years or more, $0 \%$.

The market soon perceived in this legislation a chance for circumventing the restriction: it began raising resources through issues of long term bonds (over six years), but with embedded put option clauses. This meant the foreign creditor could shorten the loan term by exercising the option. In practice, therefore, the loan was short term.

The government then began to levy a retroactive IOF if the option was exercised, and the borrower had to reverse the capital brought into the country within six years. Those interviewed in our field research stated that it was still advantageous to issue a six-year bond with a put option exercisable within one year, even with the retroactive IOF, because this did not eliminate the transaction's gains.

This case illustrates the difficulty of implementing, in practice, controls on capital inflows. It is an example of a contract subject to capital control taxes that encourages the short term investor to disguise his investments as long term while planning to recover the investment before it matures.

Since the intent of capital controls was to deter excess volatility of capital flows, the renaming of actual short term flows as long term would seriously jeopardize it. After

\footnotetext{
${ }^{24} \mathrm{CDI}$ (Interbank Certificate of Deposit) is the base overnight interest rate for transactions between financial institutions.
} 
all, if the status quo that prevailed when the investment was first made continued to hold, the short term capital would, ex post, became a long term investment. This appears to have been the case of Chile (Edwards, Valdés and De Gregorio [2000]). However, if conditions changed, and the carry-trade strategy no longer seemed to be a good deal, funds would be sent back home. The IOF tax would not be sufficient to keep the funds in the country if devaluation or default became very likely. For example, a 5\% IOF tax would be sufficient to counterbalance a devaluation of only $10 \%$ within a year with a $50 \%$ probability. After the Asian crisis, the odds for devaluation were certainly much higher than those, which explained why it was worth to issue a six-year bond and exercise the option, paying the IOF tax retroactively, if the scenario changed. Carvalho [2005] develops a dynamic model that shows that the tax rates necessary to deter capital outflows if a confidence or currency crisis became likely would be too high to be implemented.

CASE 7: Back to back Operations: Blue Chip Swaps and CC-5 transactions for avoiding the IOF on exchange rate transactions.

In August of 1995, the government tightened capital controls in an attempt to contain excessive financial capital inflows, especially short term. It raised the IOF tax on foreign capital fixed income funds from $5 \%$ to $7 \%$, raised the IOF on overseas loans from $0 \%$ to $5 \%$, prohibited foreign investments in the domestic derivatives market, ${ }^{25}$ and established a $7 \%$ IOF on operations between institutions in the country and overseas through the floating rate exchange market.

The market avoided the IOF on fixed income investments by engineering financial operations like those previously described. But the IOF on operations between domestic and international institutions drove the market to find other loopholes in the exchange rate legislation: they found what they were looking for in the famous CC-5 accounts.

The accounts of non-residents created by the Central Bank under Circular No. 5 in 1969 were a resource for facilitating the flow of foreign capital. The CC-5 allowed a non-resident institution to hold an account in Brazil in national currency with greater ease to send funds outside the country. In 1992, the CC-5 was overhauled, giving this channel greater freedom implying higher capital account convertibility. With this new structure, the CC-5 deposit could be freely remitted through the floating rate exchange market. Moreover, third-party deposits could be made to the account, which meant third parties then began to make international transfers through the CC- 5 account. This type of transfer became known later as the "International Transfer of Reais" (TIR).

Until March of 2005, to send money abroad unilaterally, a resident had to deposit it in the $\mathrm{CC}-5$ of a financial institution residing outside Brazil, then this institution would transfer it to his bank in Brazil, convert it into foreign currency, and send it overseas. The non-resident financial institution was usually an overseas branch of the domestic institution. With changes effected in March of 2005, the resident can now deposit the money directly in his bank. This simplification meant lower transaction costs and greater transparency on transfers.

\footnotetext{
${ }^{25}$ The complete prohibition of foreign investors to access domestic derivative markets was the logical culmination of the process that started with the tax on Box operations, described above. After all, there is a theorem in finance that states that any return may be reproduced by option trading if enough options are available. Therefore, taxing one strategy, as the Box, would only make the market move to another, still untaxed, one with quite similar results.
} 
Chart 12 below shows the movement of transfers through the CC-5 from January 1993 until 2004. It also contains the covered interest parity differential which is a measure of country risk. During periods of higher capital inflows to Brazil, even net inflows of capital through the CC-5 occur, as in 1995 through $1996 .^{26}$ In the exchange rate band period (1995 to 1999), the CC-5 channel was more heavily used to send resources abroad. This is associated with the greater restrictions on capital during this period and with the economic turbulence that shook the Brazilian economy, namely the crisis in Asia and the crisis in Brazil itself.

\section{CHART 12}

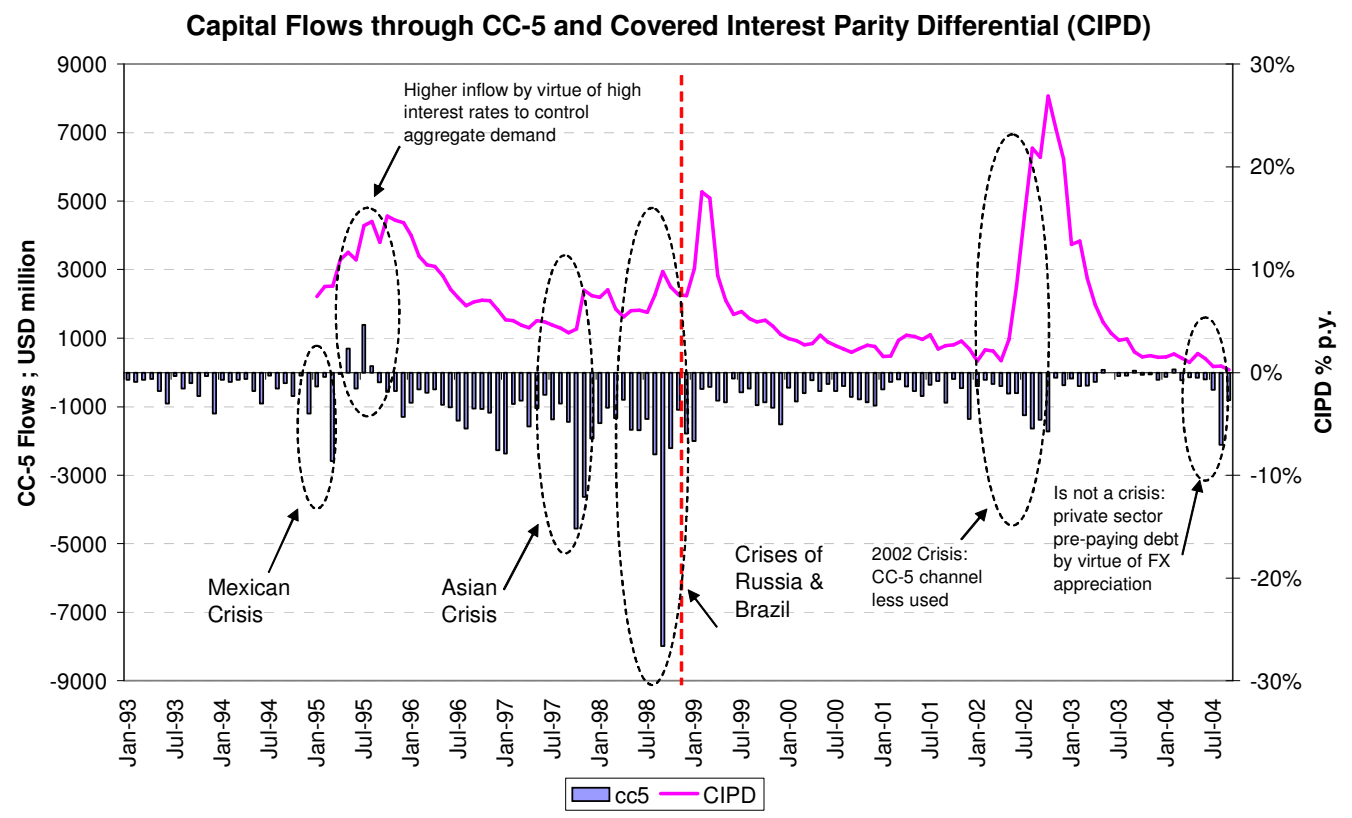

Source: Central Bank of Brazil, BM\&F and authors' calculations

The IOF established in August of 1995 on international transactions between financial institutions was assessed at the time of the exchange rate transaction (like a Tobin tax). So to bypass this tax, the market sought ways to avoid converting currency. One of these was what was called at the time a "Blue Chip Swap." This involved a foreign asset that the investor would transfer to the off-shore branch of a Brazilian financial institution against a CC-5 credit of the investor in Brazil. The foreign investor delivered the foreign asset and the domestic counterpart made the deposit in Brazil in the foreign agent's CC-5 account. Through the CC-5, the foreign investor had free access to the floating rate exchange market and sent the money abroad without restrictions when the operation was finalized. With this, international transactions between financial institutions bypassed the IOF tax by not officially converting currency.

These operations involving unofficial currency exchange, in defiance of the Central Bank's monopoly, were known as back to back operations. The Blue Chip Swap is one example of this type of operation.

\footnotetext{
${ }^{26}$ As Chart 4 clearly shows, the CC-5 net balance was clearly one of net transfers abroad. Of course, gross flows occurred both ways.
} 


\section{1 \& 2) Disguising short term investments as equity and using sophisticated financial engineering (derivatives) to avoid controls}

CASE 8: Labeling fixed income investments as equity investments II: Share loans in Brazil and Swaps abroad

The operation described in Case 3 is designed for a domestic financial intermediary that also seeks to offer off-shore mutual funds to foreign investors. In truth, these foreign investors could include Brazilians with non-declared resources abroad or those seeking to capture the advantages extended to non-residents of investing in fixed income in Brazil.

The Brazilian financial intermediary would offer its off-shore clients a mutual fund in a tax haven that profited from Brazil's short term interest rates. In theory, using Annex IV to this end was prohibited due to the capital controls. So, the financial intermediary engineered a financial transaction that enabled it to invest in fixed income via Annex IV, avoiding the restriction. With this operation, the financial intermediary was also able to save on taxes on the institution's profit in Brazil.

The strategy basically involved the financial intermediary borrowing a company's shares that had low liquidity on the BOVESPA, selling them in a buyback agreement with a foreign investor who entered under Annex IV, then conducting a swap outside the country with this investor to exchange returns. If it so desired, rather than borrowing illiquid shares, the financial intermediary could create a publicly held corporation, as in Cases 1 and 2.

Let us examine the case more thoroughly with the help of Figures 1, 2 and 3. In Figure 1 we present the operation's agents: Bank X, which was Brazilian, had a branch in the Cayman Islands and wanted to offer an off-shore mutual fund that earned the returns of Brazil's short term interest rate and whose quota holders were investors with foreign capital. The branch of Bank $\mathrm{X}$ in the tax haven managed this off-shore fund which invested in Brazilian fixed income.

FIGURE 1

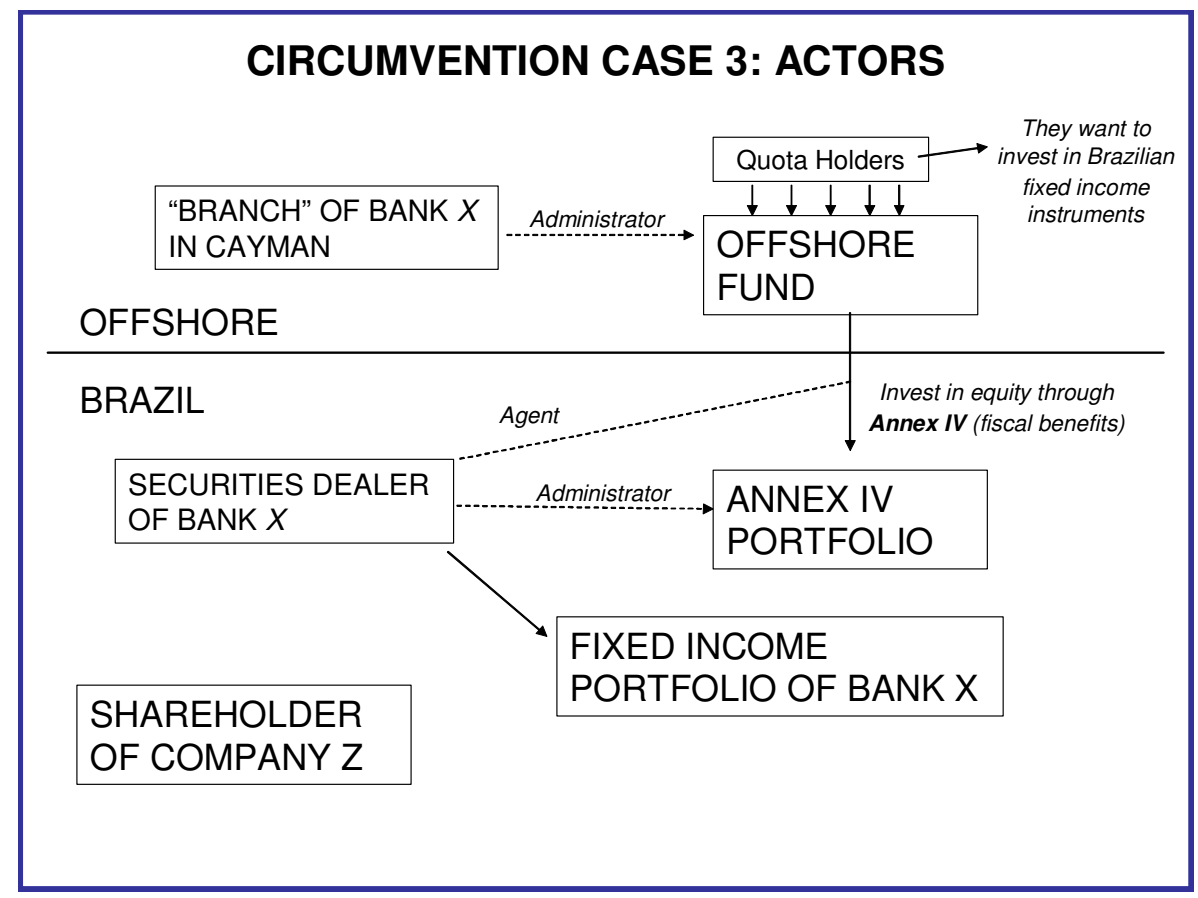


To move the fund's capital into Brazil, an Annex IV Portfolio for equity investments was opened, and it was managed by the Securities Dealer (DTVM) of Bank $\mathrm{X}$ with headquarters in Brazil. With this, the agent of the Annex IV Portfolio was the domestic Securities Dealer, as required by legislation at that time. Investments regulated by Annex IV of Resolution 1289 had to be made according to this procedure, where a qualified domestic financial institution was the agent of the foreign investor's Investment Portfolio.

The Securities Dealer of Bank X also retained its own portfolio for investments in fixed income, legally independent of this Annex IV Portfolio. The national resources of Bank X were allocated to this fixed income portfolio to capture the returns of the high domestic interest rate.

The bank also borrowed the shares of a company whose shares were listed on the BOVESPA and had very little liquidity. It's worth highlighting that this was a company that did exist physically, not one created solely for financial transactions. Illiquidity was key to prevent sudden price moves.

In Figure 2 we present the beginning of the transactions, which we divide into two steps. The second part of the transaction is illustrated in Figure 3.

\section{FIGURE 2}

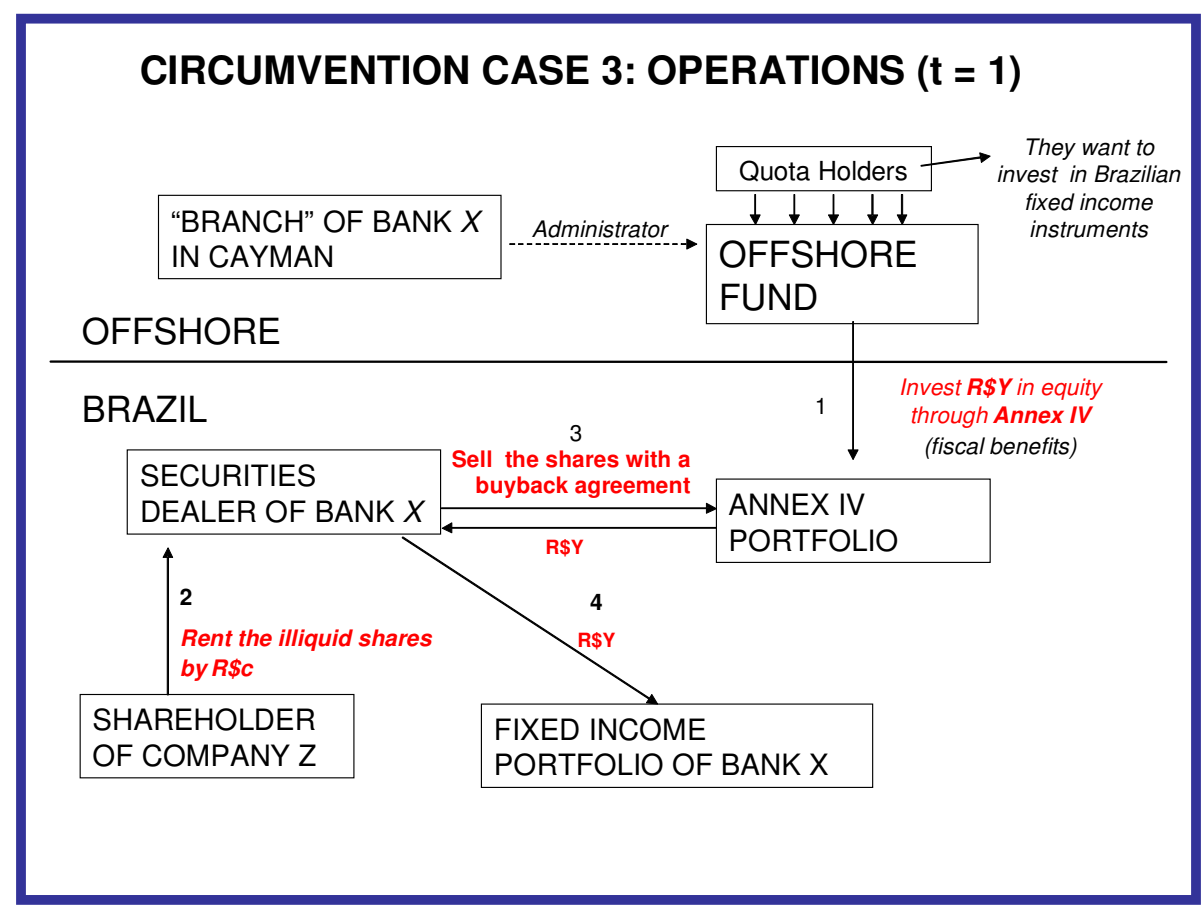

(1) The off-shore fund invested in its Annex IV Portfolio declaring its objective was obtaining returns on equity investments, which was permitted and had tax benefits. (2) The Securities Dealer of Bank X borrowed the company's shares, which we will call $\mathrm{Z}$, and (3) sold them through a buyback agreement after a specified period of time to the Annex IV Portfolio of the off-shore fund. The buyback agreement established the deadline for recovering the sale of the shares and stipulated that the buyback would be based on the share price on the day the contract expired. (4) The money from the sale of 
the shares loaned to foreign investors was invested by the Securities Dealer in its own fixed income portfolio.

The foreign investor, then, brought his resources into the country via Annex IV and transferred them to the Securities Dealer by purchasing the shares of Company Z. The Securities Dealer then invested this money in the overnight interest rate.

Figure 3 illustrates the operation's unwinding.

(5) The buyback agreement was then settled. The Annex IV Portfolio resold the shares to the bank's Securities Dealer, but since the shares had very low liquidity, their prices were easily manipulated. The bank drove the share price up and repurchased them at a price higher than that at which he had sold them to the foreign investors. All players on the financial market know that the main rule is "buy low and sell high," but in this case, the bank preferred to sell low and buy high. There was a reason for this: it enabled him to embed a loss for the Securities Dealer in this operation, reducing his profits. Bank X would then save on Brazilian taxes due on the Dealer's profit, and as we shall see, recover the loss in Cayman through the derivatives market.

(6) After buying back the loaned shares, the Securities Dealer returned them to the Company $\mathrm{Z}$ shareholder who had entered into the loan agreement. (7) The return made by the Annex IV Portfolio of the foreign investors on the share purchase operation was sent abroad legally through Annex IV, since it was gained on the stock market.

FIGURE 3

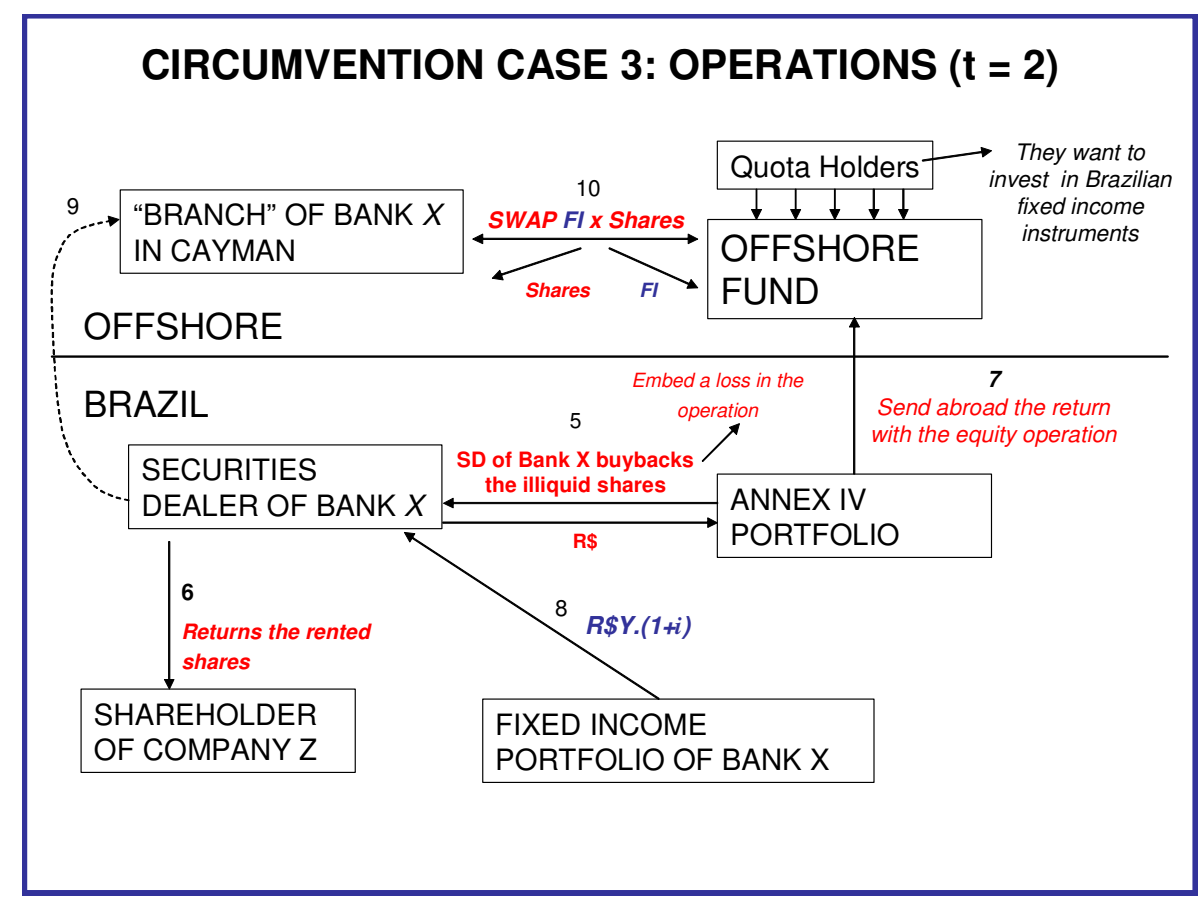

(8) The Securities Dealer obtained the returns of its fixed income portfolio. (9) The Dealer then nationalized the money in its Cayman branch, which was perfectly legal. The amount sent to the tax haven was equal to the principal plus interest earned by the fixed income portfolio, that is, the amount desired by the off-shore fund offered by the Bank X branch in Cayman. 
So, the return the off-shore fund desires was still with the Bank $\mathrm{X}$ branch in Cayman, and the loss incurred by Bank $\mathrm{X}$ in the share transaction was passed as the profit of the off-shore fund. (10) To finalize the operation and meet its objectives, the bank conducted a swap in Cayman between its branch and the off-shore fund, where they exchanged the gains from the share transaction with the fixed income returns. The swap's underlying instruments were the difference between the price of Company $\mathrm{Z}$ shares on the BOVESPA and the return on the Brazilian fixed rates, so the fixed income return went to the fund and the profit from the share transaction went to the branch of Bank X.

When concluded, the foreign investors had the fixed income returns and Bank X had saved on Brazilian taxes. The capital inflow cost incurred by this circumvention method, the $\tau^{*}$, was only the price of borrowing the shares and conducting the swap abroad, plus that of the bank to nationalize the money in its Cayman branch. The latter two items have virtually no cost, so that $\tau^{*}$ is only the cost of the share loan. But since the bank saved on taxes, $\tau^{*}$ could actually be negative, as the tax savings offset the cost of the share loan. This strategy provides a clever example of how regular corporate income taxes could also be avoided through a financial operation originally designed to avoid capital controls.

\section{II.2 - CONCLUSION OF CASES OF CAPITAL CONTROLS CIRCUMVENTION}

In this section, we have presented diverse strategies for circumventing controls on capital inflows in Brazil in the 1990s. Most strategies were designed to avoid the IOF tax on fixed income investments that was imposed with the prohibition of investments in government bonds using the Annex IV channel, although we also reviewed cases with strategies for bypassing the IOF on foreign exchange transactions and the minimum terms for foreign loans.

Controls on capital inflows in Brazil varied based on two factors: the amount of capital inflows and the means the market found to bypass restrictions.

The first point was addressed by Goldfajn and Cardoso [1997], who pointed out the endogeneity of capital controls in Brazil. In periods of heavy capital inflows, restrictions were placed on the capital inflows; and in periods of scarce foreign financing, the controls were lifted so as to attract foreign capital.

The second point was addressed in Garcia and Barcinski [1998] and in Garcia and Valpassos [2000], who pointed out the consecutive changes in legislation aimed at closing the loopholes the market found for circumventing restrictions. In fact, analyzing the composition of the total portfolio of Annex IV investments, one readily perceives the game of "cat and mouse" underway between the Central Bank / CMN and the financial market.

Table 1 shows the composition of the total portfolio of Annex IV investments from January 1993 until mid 2004 (since 1999, these investments have actually been governed by Resolution 2689).

Between January 1993 and August 1993, the "Others" item in the table accounted for around $15 \%$ to $25 \%$ of total investment. This item contained investments in government bonds that were destined for fixed income gains. Investments in government bonds directed toward privatization were discriminated in the item "Privatization Funds." The other portfolio components were investments in securities, 
derivatives and debentures. Since 2000 and the publication of Resolution 2689, the fixed income investments item has been distinguished from the "Others" item.

With the August 1993 prohibition of Annex IV fixed income investments, the $25 \%$ of "Others" in the portfolio has fallen to approximately just $1 \%$, since investments in government bonds with this objective could no longer be declared under Annex IV. The investments then had to be made via special fixed income funds for foreign capital, which incurred an IOF tax of $5 \%$ to $9 \%$.

However, in the month following this prohibition, September of 1993, the percentage of debenture investments jumped from $4 \%$ to $19 \%$, reaching $34 \%$ in November, indicating the market had begun circumventing by investing in debentures that earned fixed income, such as those of the Siderbrás Company. At the end of November of 1993, the government placed a restriction on some debenture investments, but only in February of 1996 prohibited investing in those of Siderbrás.

After debenture investments were restricted in November of 1993, the market began bypassing the IOF tax on fixed income investments using the loophole for using privatization funds and the derivatives market (using Box operations, as explained above). The table shows that the percentage of privatization funds rose in September of 2003 and peaked at almost 10\% of the Annex IV portfolio in June of 1994. The government then prohibited NTN investments as privatization resources, precluding fixed income gains through this loophole. The percentages for derivatives were only made available beginning in March of 1994, and we are unable to trace the development of these flows.

Finally, only equity investing was left unrestricted, and the other items were subject to diverse rules before permitted to invest through Annex IV. The market then began to use circumvention strategies involving the stock market, as seen in Cases 2 and 3 in the previous section. Another method that has been adopted since August of 1993 was disguising short term capital as direct investments, as described in Case 1. These two methods for circumventing the controls were not prohibited by any legal measure. Strategies such as the one in Case 2 may still be used by financial institutions seeking to avoid the income tax on fixed income gains, which is higher than that on capital market gains, or to invest in fixed income for less than 90 days without paying the 5\% IOF tax.

The market, then, appears to always find a means of circumventing restrictions placed on foreign capital, rendering capital controls ineffective in the medium term. However, the price to be paid in terms of how the market is viewed when controls are imposed could endure for some time. Some argue that ex ante controls on capital inflows do not compromise the country's reputation and are prudent measures for avoiding destabilization caused by excessive capital inflows. However, to quote one of the financial market agents that we interviewed in our field research: "An ex-alcoholic can't touch a bottle of whiskey." Also, the operations of controls on capital inflows are not very well understood, and may create misunderstandings harmful to the country's reputation. For example, in the aftermath of the Mexican 1994 crisis, Brazil reduced the IOF on capital inflows. The (albeit temporary) reduction of a tax should be considered a liberalization; however, it was taken by two highly trained scholars as just the opposite. $^{27}$

\footnotetext{
27 "Capital flows to developing countries fell by one-fifth from 1993 to 1994, with the February rise in U.S. interest rates often viewed as the turning point. At the same time, while some countries stayed the course to liberalization, others which had earlier liberalized (for example, Venezuela, Brazil, Ecuador, and Nigeria) resorted to re-imposing capital controls or to tightening existing regulations and delaying announced liberalization plans.” Drazen and Bartolini [1997]
} 
As expressed in Forbes [2003a], economic literature has still not been able to prove conclusively that imposing controls on capital inflows effectively reduces the vulnerability of the countries that employ them. Quoting Forbes [2003a]: “...although capital account liberalization may increase country vulnerability to crises in some cases, the relationship between capital controls and financial crises is not so straightforward." However, the literature extensively defends increased liberalization of the capital account: financing via foreign savings allows for more investment, increased potential GDP, and intertemporal consumption smoothing.

Our main conclusion is that although from a welfare point of view ex ante capital controls may be desirable in certain cases, their implementation when sophisticated financial markets are present is very difficult. This ineffectiveness comes from three facts:

1) developed financial markets are very good in performing arbitrage;

2) capital is fungible;

3) usually, a country wants to control only a few forms of capital inflows (e.g., short-term portfolio investments) while providing total freedom to other forms (e.g., long term fixed investment).

With these three characteristics financial markets can lower the cost of effectively investing in the country, as we have documented for Brazil. ${ }^{28}$

\footnotetext{
${ }^{28}$ One market player remarked that things may have changed somewhat in regards to the ability of the financial market to avoid controls. This would be because current legislation carries penal liabilities to the partners of institutions that are found guilty of breaching the legislation. Therefore, financial market players may have become more risk averse in devising financial engineering strategies to avoid capital controls, but that remains to be seen.
} 
TABLE 1 - Composition of Annex IV Channel for Financial Inflow

\begin{tabular}{|c|c|c|c|c|c|c|}
\hline & \multicolumn{6}{|c|}{ Annex IV Composition (\% Total) } \\
\hline & $\begin{array}{l}\text { Portfolio } \\
\text { Value } \\
\text { US\$ bilhões }\end{array}$ & $\begin{array}{c}\text { Equity } \\
\%\end{array}$ & $\begin{array}{c}\text { Derivatives } \\
\%\end{array}$ & $\begin{array}{c}\text { Debentures } \\
\%\end{array}$ & $\begin{array}{c}\text { Privatization } \\
\text { Currency } \\
\%\end{array}$ & $\begin{array}{c}\text { Others } \\
\%\end{array}$ \\
\hline jan-93 & 2.37 & $82.50 \%$ & $0.00 \%$ & $2.30 \%$ & $0.00 \%$ & $15.20 \%$ \\
\hline fev-93 & 2.35 & $73.90 \%$ & $0.00 \%$ & $4.80 \%$ & $0.80 \%$ & $20.50 \%$ \\
\hline mar-93 & 2.49 & $85.00 \%$ & $0.00 \%$ & $0.30 \%$ & $1.50 \%$ & $\begin{array}{l}13.20 \% \\
17.10 \%\end{array}$ \\
\hline abr-93 & $\begin{array}{l}3.42 \\
4.05\end{array}$ & $79.00 \%$ & $0.00 \%$ & $3.80 \%$ & $0.10 \%$ & $\begin{array}{l}17.10 \% \\
17.70 \%\end{array}$ \\
\hline $\begin{array}{l}\text { mai-93 } \\
\text { jun-93 }\end{array}$ & $\begin{array}{l}4.05 \\
4.83\end{array}$ & $\begin{array}{l}80.00 \% \\
82.60 \%\end{array}$ & $\begin{array}{l}0.00 \% \\
0.00 \%\end{array}$ & $\begin{array}{l}2.20 \% \\
2.70 \%\end{array}$ & $\begin{array}{l}0.10 \% \\
0.10 \%\end{array}$ & $\begin{array}{l}17.70 \% \\
14.60 \%\end{array}$ \\
\hline jul-93 & 5.15 & $73.50 \%$ & $0.00 \%$ & $4.80 \%$ & $0.10 \%$ & $21.60 \%$ \\
\hline ago-93 & 6.88 & $70.30 \%$ & $0.00 \%$ & $4.00 \%$ & $0.50 \%$ & $25.20 \%$ \\
\hline set-93 & 6.76 & $77.20 \%$ & $0.00 \%$ & $19.00 \%$ & $2.60 \%$ & $1.20 \%$ \\
\hline $\begin{array}{l}\text { out }-93 \\
\text { nov-93 }\end{array}$ & $\begin{array}{l}7.45 \\
8.96\end{array}$ & $\begin{array}{l}68.20 \% \\
65.20 \%\end{array}$ & $\begin{array}{l}0.00 \% \\
0.00 \%\end{array}$ & $\begin{array}{l}29.30 \% \\
33.60 \%\end{array}$ & $\begin{array}{l}1.60 \% \\
0.90 \%\end{array}$ & $\begin{array}{l}0.90 \% \\
0.30 \%\end{array}$ \\
\hline dez-93 & 10.38 & $80.10 \%$ & $0.00 \%$ & $18.50 \%$ & $1.10 \%$ & $0.30 \%$ \\
\hline jan-94 & 12.12 & $82.50 \%$ & $0.00 \%$ & $15.90 \%$ & $1.40 \%$ & $0.20 \%$ \\
\hline fev-94 & 13.23 & $83.32 \%$ & $0.00 \%$ & $14.14 \%$ & $2.33 \%$ & $0.21 \%$ \\
\hline mar-94 & 14.51 & $78.26 \%$ & $4.93 \%$ & $13.31 \%$ & $3.40 \%$ & $0.10 \%$ \\
\hline$a b r-94$ & 12.83 & $75.32 \%$ & $4.19 \%$ & $15.97 \%$ & $4.44 \%$ & $0.08 \%$ \\
\hline mai-94 & 12.97 & $67.90 \%$ & $7.60 \%$ & $16.10 \%$ & $8.33 \%$ & $0.07 \%$ \\
\hline jun-94 & 13.57 & $66.68 \%$ & $8.60 \%$ & $15.16 \%$ & $9.49 \%$ & $0.07 \%$ \\
\hline jul-94 & 16.15 & $70.99 \%$ & $5.66 \%$ & $15.12 \%$ & $7.84 \%$ & $0.39 \%$ \\
\hline ago-94 & 21.31 & $73.40 \%$ & $5.40 \%$ & $11.20 \%$ & $5.20 \%$ & $4.80 \%$ \\
\hline set-94 & 21.61 & $78.10 \%$ & $3.20 \%$ & $12.30 \%$ & $5.00 \%$ & $1.40 \%$ \\
\hline out-94 & 20.77 & $77.35 \%$ & $4.06 \%$ & $12.72 \%$ & $5.13 \%$ & $0.74 \%$ \\
\hline $\begin{array}{l}\text { nov-94 } \\
\text { dez-94 }\end{array}$ & $\begin{array}{l}21.83 \\
20.97\end{array}$ & $\begin{array}{l}78.62 \% \\
77.54 \%\end{array}$ & $\begin{array}{l}4.02 \% \\
3.85 \%\end{array}$ & $\begin{array}{l}11.15 \% \\
12.41 \%\end{array}$ & $\begin{array}{l}5.56 \% \\
5.41 \%\end{array}$ & $\begin{array}{l}0.65 \% \\
0.79 \%\end{array}$ \\
\hline jan-95 & 17.84 & $76.69 \%$ & $1.95 \%$ & $13.93 \%$ & $5.86 \%$ & $1.57 \%$ \\
\hline fev-95 & 15.76 & $77.44 \%$ & $3.20 \%$ & $12.20 \%$ & $6.20 \%$ & $0.96 \%$ \\
\hline mar-95 & 13.30 & $82.77 \%$ & $1.43 \%$ & $8.43 \%$ & $4.26 \%$ & $3.11 \%$ \\
\hline $\begin{array}{l}\text { abr-95 } \\
m a i-95\end{array}$ & $\begin{array}{l}15.08 \\
16.99\end{array}$ & $\begin{array}{l}84.87 \% \\
85.84 \%\end{array}$ & $\begin{array}{l}2.32 \% \\
1.24 \%\end{array}$ & $\begin{array}{l}6.80 \% \\
7.89 \%\end{array}$ & $\begin{array}{l}5.24 \% \\
4.39 \%\end{array}$ & $\begin{array}{l}0.77 \% \\
0.64 \%\end{array}$ \\
\hline jun-95 & 16.92 & $85.19 \%$ & $2.13 \%$ & $7.61 \%$ & $4.42 \%$ & $0.65 \%$ \\
\hline jul-95 & 18.58 & $84.78 \%$ & $2.96 \%$ & $7.57 \%$ & $4.12 \%$ & $0.57 \%$ \\
\hline ago-95 & 20.63 & $86.46 \%$ & $3.19 \%$ & $5.94 \%$ & $3.75 \%$ & $0.66 \%$ \\
\hline set-95 & 19.75 & $86.35 \%$ & $3.01 \%$ & $6.02 \%$ & $4.12 \%$ & $0.50 \%$ \\
\hline out-95 & 18.97 & $86.51 \%$ & $1.89 \%$ & $7.22 \%$ & $3.79 \%$ & $0.58 \%$ \\
\hline nov-95 & 18.81 & $88.95 \%$ & $0.66 \%$ & $4.95 \%$ & $3.72 \%$ & $1.72 \%$ \\
\hline dez-95 & 18.65 & $89.46 \%$ & $1.09 \%$ & $5.54 \%$ & $3.68 \%$ & $0.23 \%$ \\
\hline jan-96 & 20.29 & $90.84 \%$ & $0.04 \%$ & $4.72 \%$ & $3.52 \%$ & $0.88 \%$ \\
\hline $\begin{array}{l}\text { fev-96 } \\
\text { mar-96 }\end{array}$ & $\begin{array}{l}20.33 \\
19.27\end{array}$ & $\begin{array}{l}90.33 \% \\
89.79 \%\end{array}$ & $\begin{array}{l}0.04 \% \\
0.09 \%\end{array}$ & $\begin{array}{l}4.46 \% \\
4.75 \%\end{array}$ & $\begin{array}{l}4.14 \% \\
4.32 \%\end{array}$ & $\begin{array}{l}1.03 \% \\
1.05 \%\end{array}$ \\
\hline$a b r-96$ & 19.77 & $89.16 \%$ & $0.09 \%$ & $5.64 \%$ & $3.92 \%$ & $1.19 \%$ \\
\hline $\begin{array}{l}\text { mai-96 } \\
\text { jun-96 }\end{array}$ & $\begin{array}{l}21.21 \\
23.33\end{array}$ & $\begin{array}{l}90.09 \% \\
91.11 \%\end{array}$ & $\begin{array}{l}0.05 \% \\
0.03 \%\end{array}$ & $\begin{array}{l}5.66 \% \\
4.48 \%\end{array}$ & $\begin{array}{l}3.48 \% \\
3.21 \%\end{array}$ & $\begin{array}{l}0.72 \% \\
1.17 \%\end{array}$ \\
\hline jul-96 & 23.28 & $90.22 \%$ & $0.00 \%$ & $5.65 \%$ & $3.59 \%$ & $0.54 \%$ \\
\hline ago-96 & 24.07 & $90.51 \%$ & $0.00 \%$ & $5.52 \%$ & $3.45 \%$ & $0.52 \%$ \\
\hline set-96 & 25.03 & $91.06 \%$ & $0.00 \%$ & $5.63 \%$ & $3.19 \%$ & $0.12 \%$ \\
\hline out-96 & 25.71 & $91.22 \%$ & $0.00 \%$ & $5.58 \%$ & $3.27 \%$ & $-0.07 \%$ \\
\hline nov-96 & 26.63 & $91.53 \%$ & $0.00 \%$ & $5.50 \%$ & $3.20 \%$ & $-0.23 \%$ \\
\hline dez-96 & 28.16 & $91.96 \%$ & $0.00 \%$ & $5.72 \%$ & $2.79 \%$ & $-0.47 \%$ \\
\hline jan-97 & 31.71 & $92.58 \%$ & $0.00 \%$ & $4.85 \%$ & $2.11 \%$ & $0.46 \%$ \\
\hline fev-97 & 34.75 & $93.06 \%$ & $0.00 \%$ & $4.45 \%$ & $1.94 \%$ & $0.55 \%$ \\
\hline mar-97 & 36.35 & $93.30 \%$ & $0.00 \%$ & $4.32 \%$ & $1.88 \%$ & $0.50 \%$ \\
\hline$a b r-97$ & 38.89 & $94.21 \%$ & $0.00 \%$ & $3.65 \%$ & $1.74 \%$ & $0.40 \%$ \\
\hline mai-97 & 40.94 & $94.85 \%$ & $0.00 \%$ & $3.29 \%$ & $0.19 \%$ & $1.67 \%$ \\
\hline jun-97 & 46.03 & $95.16 \%$ & $0.93 \%$ & $2.99 \%$ & $0.92 \%$ & $0.00 \%$ \\
\hline jul-97 & 49.89 & $95.47 \%$ & $0.69 \%$ & $3.00 \%$ & $0.84 \%$ & $0.00 \%$ \\
\hline ago-97 & 42.64 & $94.79 \%$ & $0.63 \%$ & $3.71 \%$ & $0.87 \%$ & $0.00 \%$ \\
\hline set-97 & 46.11 & $95.24 \%$ & $0.56 \%$ & $3.37 \%$ & $0.83 \%$ & $0.00 \%$ \\
\hline out-97 & 35.56 & $94.43 \%$ & $0.88 \%$ & $4.00 \%$ & $0.69 \%$ & $0.00 \%$ \\
\hline nov-97 & 34.73 & $95.67 \%$ & $0.52 \%$ & $3.08 \%$ & $0.72 \%$ & $0.01 \%$ \\
\hline dez-97 & 35.78 & $96.46 \%$ & $1.39 \%$ & $2.12 \%$ & $0.00 \%$ & $0.03 \%$ \\
\hline jan-98 & 29.19 & $95.75 \%$ & $1.93 \%$ & $2.28 \%$ & $0.03 \%$ & $0.01 \%$ \\
\hline fev-98 & 30.90 & $96.38 \%$ & $1.48 \%$ & $2.11 \%$ & $0.03 \%$ & $0.00 \%$ \\
\hline mar-98 & 34.87 & $97.30 \%$ & $1.27 \%$ & $1.40 \%$ & $0.02 \%$ & $0.00 \%$ \\
\hline$a b r-98$ & 35.31 & $96.49 \%$ & $2.04 \%$ & $1.45 \%$ & $0.02 \%$ & $0.00 \%$ \\
\hline mai-98 & 30.06 & $96.67 \%$ & $1.57 \%$ & $1.73 \%$ & $0.03 \%$ & $0.00 \%$ \\
\hline jun-98 & 28.72 & $96.50 \%$ & $1.57 \%$ & $1.73 \%$ & $0.03 \%$ & $0.17 \%$ \\
\hline $\begin{array}{l}\text { jul-98 } \\
\text { ago-98 }\end{array}$ & $\begin{array}{l}30.97 \\
20.21\end{array}$ & $\begin{array}{l}96.69 \% \\
94.57 \%\end{array}$ & $\begin{array}{l}1.66 \% \\
2.53 \%\end{array}$ & $\begin{array}{l}1.62 \% \\
2.86 \%\end{array}$ & $\begin{array}{l}0.03 \% \\
0.04 \%\end{array}$ & $\begin{array}{l}0.00 \% \\
0.01 \%\end{array}$ \\
\hline set-98 & 17.21 & $95.25 \%$ & $3.48 \%$ & $1.22 \%$ & $0.05 \%$ & $0.00 \%$ \\
\hline out-98 & 18.00 & $95.49 \%$ & $3.37 \%$ & $1.11 \%$ & $0.04 \%$ & $0.00 \%$ \\
\hline nov-98 & 21.42 & $96.84 \%$ & $2.30 \%$ & $0.83 \%$ & $0.03 \%$ & $0.00 \%$ \\
\hline dez-98 & 17.37 & $94.80 \%$ & $4.16 \%$ & $1.00 \%$ & $0.04 \%$ & $0.00 \%$ \\
\hline
\end{tabular}




\begin{tabular}{|c|c|c|c|c|c|c|c|}
\hline & $\begin{array}{l}\text { Portfolio } \\
\text { Value } \\
\text { USD B illion }\end{array}$ & $\begin{array}{c}\text { Fixed Income } \\
\%\end{array}$ & $\begin{array}{c}\text { Equity } \\
\%\end{array}$ & $\begin{array}{c}\text { Derivatives } \\
\%\end{array}$ & $\begin{array}{c}\text { Debentures } \\
\%\end{array}$ & $\begin{array}{c}\text { Privatization } \\
\text { Currency } \\
\%\end{array}$ & $\begin{array}{c}\text { Others } \\
\%\end{array}$ \\
\hline $\begin{array}{l}\text { jan-99 } \\
\text { fev-99 }\end{array}$ & $\begin{array}{l}11.85 \\
11.83\end{array}$ & & $\begin{array}{l}94.90 \% \\
95.50 \%\end{array}$ & $\begin{array}{l}3.85 \% \\
3.59 \%\end{array}$ & $\begin{array}{l}0.81 \% \\
0.71 \%\end{array}$ & $\begin{array}{l}0.00 \% \\
0.07 \%\end{array}$ & $\begin{array}{l}0.43 \% \\
0.13 \%\end{array}$ \\
\hline mar-99 & 16.02 & & $97.60 \%$ & $1.61 \%$ & $0.60 \%$ & $0.10 \%$ & $0.10 \%$ \\
\hline$a b r-99$ & 18.04 & & $97.90 \%$ & $1.42 \%$ & $0.46 \%$ & $0.20 \%$ & $0.03 \%$ \\
\hline mai-99 & 17.54 & & $98.40 \%$ & $0.90 \%$ & $0.52 \%$ & $0.20 \%$ & $-0.02 \%$ \\
\hline jun-99 & 18.23 & & $98.76 \%$ & $0.23 \%$ & $0.72 \%$ & $0.29 \%$ & $0.00 \%$ \\
\hline jul-99 & 17.09 & & $98.95 \%$ & $0.19 \%$ & $0.69 \%$ & $0.15 \%$ & $0.02 \%$ \\
\hline $\begin{array}{l}\text { ago-99 } \\
\text { set-99 }\end{array}$ & $\begin{array}{l}15.90 \\
17.51\end{array}$ & & $\begin{array}{l}98.72 \% \\
98.72 \%\end{array}$ & $\begin{array}{l}0.02 \% \\
0.02 \%\end{array}$ & $\begin{array}{l}0.92 \% \\
0.87 \%\end{array}$ & $\begin{array}{l}0.10 \% \\
0.30 \%\end{array}$ & $\begin{array}{l}0.24 \% \\
0.10 \%\end{array}$ \\
\hline $\begin{array}{l}\text { out-99 } \\
\text { nov-99 }\end{array}$ & $\begin{array}{l}17.79 \\
20.00\end{array}$ & & $\begin{array}{l}98.70 \% \\
98.77 \%\end{array}$ & $\begin{array}{l}0.08 \% \\
0.09 \%\end{array}$ & $\begin{array}{l}0.83 \% \\
0.81 \%\end{array}$ & $\begin{array}{l}0.28 \% \\
0.20 \%\end{array}$ & $\begin{array}{l}0.11 \% \\
0.13 \%\end{array}$ \\
\hline $\begin{array}{l}\text { dez-99 } \\
\text { jan-00 }\end{array}$ & $\begin{array}{l}23.11 \\
22.32\end{array}$ & & $\begin{array}{l}98.98 \% \\
98.48 \%\end{array}$ & $\begin{array}{l}0.04 \% \\
0.09 \%\end{array}$ & $\begin{array}{l}0.82 \% \\
1.17 \%\end{array}$ & $\begin{array}{l}0.02 \% \\
0.01 \%\end{array}$ & $\begin{array}{l}0.14 \% \\
0.25 \%\end{array}$ \\
\hline fev-0o & 22.95 & & $98.49 \%$ & $0.07 \%$ & $1.26 \%$ & $0.01 \%$ & $0.17 \%$ \\
\hline mar-00 & 23.10 & & $98.44 \%$ & $0.06 \%$ & $1.29 \%$ & $0.01 \%$ & $0.20 \%$ \\
\hline$a b r-00$ & 22.45 & $1.76 \%$ & $96.83 \%$ & $0.05 \%$ & $1.36 \%$ & $0.01 \%$ & $-0.01 \%$ \\
\hline mai-00 & 20.05 & $2.28 \%$ & $96.42 \%$ & $0.11 \%$ & $1.19 \%$ & $0.01 \%$ & $-0.01 \%$ \\
\hline jun-00 & 23.07 & $4.61 \%$ & $94.13 \%$ & $0.10 \%$ & $1.15 \%$ & $0.01 \%$ & $-0.01 \%$ \\
\hline jul-00 & 23.58 & $6.62 \%$ & $91.63 \%$ & $0.05 \%$ & $1.24 \%$ & $0.01 \%$ & $0.45 \%$ \\
\hline ago-00 & 23.61 & $5.77 \%$ & $92.67 \%$ & $0.13 \%$ & $1.23 \%$ & $0.01 \%$ & $0.19 \%$ \\
\hline set-00 & 21.09 & $5.92 \%$ & $92.52 \%$ & $0.16 \%$ & $1.27 \%$ & $0.01 \%$ & $0.12 \%$ \\
\hline out-0o & 18.93 & $6.93 \%$ & $91.48 \%$ & $0.15 \%$ & $1.31 \%$ & $0.01 \%$ & $0.12 \%$ \\
\hline nov-00 & 17.78 & $7.50 \%$ & $90.89 \%$ & $0.24 \%$ & $1.26 \%$ & $0.01 \%$ & $0.10 \%$ \\
\hline dez-00 & 18.53 & $7.04 \%$ & $91.92 \%$ & $0.05 \%$ & $0.91 \%$ & $0.01 \%$ & $0.07 \%$ \\
\hline jan-01 & 21.25 & $6.37 \%$ & $92.58 \%$ & $0.10 \%$ & $0.89 \%$ & $0.01 \%$ & $0.05 \%$ \\
\hline$f e v-01$ & 18.55 & $6.84 \%$ & $92.35 \%$ & $0.05 \%$ & $0.67 \%$ & $0.01 \%$ & $0.08 \%$ \\
\hline mar-01 & 17.09 & $9.27 \%$ & $89.71 \%$ & $0.16 \%$ & $0.78 \%$ & $0.01 \%$ & $0.07 \%$ \\
\hline$a b r-01$ & 18.65 & $9.66 \%$ & $89.20 \%$ & $0.26 \%$ & $0.84 \%$ & $0.01 \%$ & $0.03 \%$ \\
\hline mai-01 & 17.75 & $10.59 \%$ & $88.32 \%$ & $0.23 \%$ & $0.80 \%$ & $0.01 \%$ & $0.04 \%$ \\
\hline jun-01 & 17.82 & $9.61 \%$ & $89.47 \%$ & $0.14 \%$ & $0.72 \%$ & $0.01 \%$ & $0.04 \%$ \\
\hline jul-01 & 15.81 & $11.93 \%$ & $87.17 \%$ & $0.15 \%$ & $0.70 \%$ & $0.01 \%$ & $0.04 \%$ \\
\hline ago-01 & 14.62 & $12.20 \%$ & $86.47 \%$ & $0.55 \%$ & $0.72 \%$ & $0.01 \%$ & $0.05 \%$ \\
\hline set-01 & 13.99 & $20.94 \%$ & $75.99 \%$ & $0.70 \%$ & $2.33 \%$ & $0.01 \%$ & $0.03 \%$ \\
\hline out-01 & 13.67 & $17.52 \%$ & $78.67 \%$ & $0.16 \%$ & $2.79 \%$ & $0.01 \%$ & $0.85 \%$ \\
\hline $\begin{array}{l}\text { nov-01 } \\
\text { dez-01 }\end{array}$ & $\begin{array}{l}14.42 \\
15.50\end{array}$ & $\begin{array}{c}11.86 \% \\
9.32 \%\end{array}$ & $\begin{array}{l}85.02 \% \\
88.45 \%\end{array}$ & $\begin{array}{l}0.50 \% \\
0.29 \%\end{array}$ & $\begin{array}{l}1.54 \% \\
0.73 \%\end{array}$ & $\begin{array}{l}0.01 \% \\
0.01 \%\end{array}$ & $\begin{array}{l}1.07 \% \\
1.20 \%\end{array}$ \\
\hline jan-02 & 14.59 & $9.73 \%$ & $87.44 \%$ & $0.75 \%$ & $0.67 \%$ & $0.01 \%$ & $1.41 \%$ \\
\hline$f e v-02$ & 16.57 & $8.37 \%$ & $89.08 \%$ & $1.97 \%$ & $0.34 \%$ & $0.01 \%$ & $0.22 \%$ \\
\hline mar-02 & 16.34 & $8.52 \%$ & $90.24 \%$ & $0.41 \%$ & $0.60 \%$ & $0.01 \%$ & $0.22 \%$ \\
\hline a br-02 & 16.78 & $8.27 \%$ & $89.55 \%$ & $1.48 \%$ & $0.59 \%$ & $0.01 \%$ & $0.11 \%$ \\
\hline mai-02 & 15.02 & $8.19 \%$ & $89.72 \%$ & $1.38 \%$ & $0.59 \%$ & $0.01 \%$ & $0.11 \%$ \\
\hline jun-02 & 12.31 & $9.68 \%$ & $87.50 \%$ & $2.03 \%$ & $0.67 \%$ & $0.01 \%$ & $0.11 \%$ \\
\hline jul-02 & 9.18 & $11.90 \%$ & $83.20 \%$ & $4.21 \%$ & $0.57 \%$ & $0.01 \%$ & $0.11 \%$ \\
\hline ago-02 & 10.22 & $10.16 \%$ & $85.56 \%$ & $3.64 \%$ & $0.43 \%$ & $0.01 \%$ & $0.20 \%$ \\
\hline set-02 & 9.96 & $16.92 \%$ & $77.29 \%$ & $5.19 \%$ & $0.43 \%$ & $0.01 \%$ & $0.16 \%$ \\
\hline out-02 & 8.95 & $15.67 \%$ & $79.97 \%$ & $3.14 \%$ & $1.01 \%$ & $0.01 \%$ & $0.20 \%$ \\
\hline nov-02 & 9.06 & $16.94 \%$ & $78.75 \%$ & $3.02 \%$ & $1.11 \%$ & $0.01 \%$ & $0.17 \%$ \\
\hline dez-02 & 10.40 & $21.51 \%$ & $74.70 \%$ & $2.35 \%$ & $1.15 \%$ & $0.01 \%$ & $0.27 \%$ \\
\hline jan-03 & 10.04 & $22.72 \%$ & $73.84 \%$ & $1.88 \%$ & $1.24 \%$ & $0.01 \%$ & $0.30 \%$ \\
\hline $\begin{array}{l}\text { fev-03 } \\
\text { mar-03 }\end{array}$ & $\begin{array}{c}9.85 \\
10.68\end{array}$ & $\begin{array}{l}22.99 \% \\
18.93 \%\end{array}$ & $\begin{array}{l}72.13 \% \\
76.43 \%\end{array}$ & $\begin{array}{l}3.26 \% \\
2.85 \%\end{array}$ & $\begin{array}{l}1.29 \% \\
1.47 \%\end{array}$ & $\begin{array}{l}0.01 \% \\
0.01 \%\end{array}$ & $\begin{array}{l}0.32 \% \\
0.31 \%\end{array}$ \\
\hline a br-03 & 12.48 & $17.41 \%$ & $78.06 \%$ & $2.69 \%$ & $1.43 \%$ & $0.01 \%$ & $0.40 \%$ \\
\hline mai-03 & 12.64 & $16.50 \%$ & $80.01 \%$ & $1.71 \%$ & $1.39 \%$ & $0.01 \%$ & $0.38 \%$ \\
\hline jun-03 & 12.80 & $9.90 \%$ & $80.30 \%$ & $1.20 \%$ & $1.40 \%$ & $0.01 \%$ & $7.19 \%$ \\
\hline jul-03 & 13.31 & $15.60 \%$ & $80.94 \%$ & $1.44 \%$ & $1.50 \%$ & $0.01 \%$ & $0.51 \%$ \\
\hline ago-03 & 14.60 & $14.13 \%$ & $82.81 \%$ & $1.19 \%$ & $1.38 \%$ & $0.01 \%$ & $0.48 \%$ \\
\hline set-03 & 15.05 & $13.26 \%$ & $83.94 \%$ & $1.07 \%$ & $1.24 \%$ & $0.01 \%$ & $0.48 \%$ \\
\hline out-03 & 18.68 & $17.23 \%$ & $76.76 \%$ & $4.61 \%$ & $0.95 \%$ & $0.01 \%$ & $0.43 \%$ \\
\hline nov-03 & 17.64 & $11.63 \%$ & $86.10 \%$ & $0.82 \%$ & $0.94 \%$ & $0.01 \%$ & $0.50 \%$ \\
\hline dez-03 & 20.12 & $11.60 \%$ & $86.79 \%$ & $0.62 \%$ & $0.68 \%$ & $0.01 \%$ & $0.30 \%$ \\
\hline jan-04 & 20.02 & $11.69 \%$ & $86.84 \%$ & $0.61 \%$ & $0.57 \%$ & $0.01 \%$ & $0.28 \%$ \\
\hline fev-04 & 20.72 & $12.30 \%$ & $86.30 \%$ & $0.50 \%$ & $0.60 \%$ & $0.01 \%$ & $0.29 \%$ \\
\hline mar-04 & 20.96 & $12.51 \%$ & $86.02 \%$ & $0.55 \%$ & $0.57 \%$ & $0.00 \%$ & $0.35 \%$ \\
\hline a br-04 & 20.40 & $11.67 \%$ & $85.21 \%$ & $2.29 \%$ & $0.57 \%$ & $0.00 \%$ & $0.26 \%$ \\
\hline mai-04 & 18.41 & $10.62 \%$ & $87.40 \%$ & $1.10 \%$ & $0.65 \%$ & $0.00 \%$ & $0.23 \%$ \\
\hline jun-04 & 18.50 & $9.94 \%$ & $87.67 \%$ & $1.31 \%$ & $0.84 \%$ & $0.00 \%$ & $0.24 \%$ \\
\hline
\end{tabular}




\section{V - CONCLUSION}

We have analyzed the effectiveness of controls on capital inflows in restricting and selecting financial inflows. We saw that in Brazil in the 1990s, controls on capital inflows only effectively limited financial inflows for short periods: two to six months. The hypothesis we submitted was that operations aimed at avoiding capital controls during this period rendered ineffective the measures and restrictions. We gave numerous examples of the operations that were reportedly used in this period, and that allowed external investors to invest in Brazil while bypassing government restrictions.

The ability to circumvent controls on capital inflows implies that the cost of short term capital inflows is not necessarily the official tax rate imposed by the capital controls, but rather the lesser of the two between the official tax rate and the cost of avoiding the controls. We reported numerous cases in Brazil during the 1990s that showed that the cost of circumventing capital controls in that period was less than that of complying with regulation. As such, the effectiveness of measures restricting capital inflows was very limited. We conducted an analysis using impulse response functions to measure the effectiveness of inflow controls in restricting financial inflows in Brazil in the 1990s, and we found that the measures were able to reduce capital inflows for up to six months. Financial inflows through the Annex IV channel - which were often seen as the short term villains at the time - were even less affected, and reversed the impact of the restriction in only two to three months.

The impact of capital controls avoidance on their effectiveness has not yet been thoroughly addressed in economic literature. It is common to assume that implementation of the controls is a given, and to disregard the effect of circumvention. However, the imposition of capital controls will be influenced by the following factors: the development of the domestic financial market and alternatives in overseas derivatives markets (which enlarge avoidance alternatives); the ability of authorities to monitor inflows; the penalties for avoidance; and, the most difficult to prevent, regulation loopholes.

In summary, the effectiveness of controls on capital inflows will depend on the market's ability to circumvent restrictions and the government's ability to establish a covered interest parity differential that will balance capital flows. As long as the country's risk-adjusted earnings are attractive for the carry-trade strategy, controls on capital inflows will be at best only temporarily effective in a developed, sophisticated financial market. And policy-makers should take this restriction into account when designing economic policies. Capital controls may very well be desirable, a topic we do not discuss here. But if they are ineffective, there is no point in spending the scarce resources of bank supervision trying to implement them. Instead, improving economic policy should be the main focus. 


\section{VI - REFERENCES}

Arida, P. [2003] - "Aspectos Macroeconômicos da Conversibilidade: o Caso Brasileiro", IEPE Casa das Garças, www.casadasgarcas.com .

Arida, P., Bacha, E. and Resende, A. [2005] - "Credit, Interest, and Jurisdictional Uncertainty: Conjectures on the Case of Brasil", in F. Giavazzi, I. Goldfajn, and S. Herrera, eds., Inflation Targeting, Debt, and the Brazilian Experience, 1999 to 2003, The MIT Press.

Baldini Júnior, R. [2001] - "Controles de Capital no Chile”, Nota Técnica do Banco Central do Brasil.

Bevilaqua, A. , Garcia, M. , de Paula, A. [2001] - "Efeitos da Consolidação do Mercosul nos Mecanismos de Captação de Poupança Externa", in Bauman, R. (Org.). Mecosul: avanços e desafios da integração. Brasília, DF, 2001, p. 439-478.

Banco Central do Brasil [1997] - Relatório do Banco Central do Brasil: 1996 , Brasília Banco Central do Brasil [1998] - Relatório do Banco Central do Brasil: 1997 , Brasília Banco Central do Brasil [1999] - Relatório do Banco Central do Brasil: 1998 , Brasília Banco Central do Brasil [2000] - Relatório do Banco Central do Brasil: 1999 , Brasília Banco Central do Brasil [2001] - Relatório do Banco Central do Brasil: 2000 , Brasília Banco Central do Brasil [2002] - Relatório do Banco Central do Brasil: 2001 , Brasília Banco Central do Brasil [2003] - Relatório do Banco Central do Brasil: 2002 , Brasília Banco Central do Brasil [2004] - Relatório do Banco Central do Brasil: 2003 , Brasília

Cardoso, E., Goldfajn , I. [1997] - "Capital Flows to Brazil: The Endogeneity of Capital Controls”, IMF Working Paper \# 97/115, September.

Carvalho, Bernardo S. de M. [2005] - "A eficácia dos controles de entrada de capitais no Brasil", Master Thesis PUC-Rio.

Chan, N., Getmansky, M., Haas, S. and Lo, A. [2006] - "Systemic Risk and Hedge Funds", Paper presented at Financial Markets Conference 2006, Federal Reserve Bank of Atlanta, May.

Cordella, T. [1998] - "Can Short-Term Capital Controls Promote Capital Inflows?", IMF Working Paper WP/98/131, October.

Cowan, K, De Gregorio, J. [2005] - "International Borrowing, Capital Controls and the Exchange Rate Lessons from Chile”, NBER, WP \# 11382, May.

Dixit, A. , Pindyck,R. [1994] - Investment Under Uncertainty, Princeton University 
Press.

Dooley, M. [1995] - "A Survey of Academic Literature on Controls over International Capital Transactions”, NBER, WP \# 5352.

Dornbusch, R. [1998] - "Capital Controls: An Idea Whose Time is Past", in Should the IMF Pursue Capital Account Convertibility?, Essays in International Finance No. 207, Princeton University.

Duffie, D., Singleton, K. [2003] - Credit Risk: Pricing, Measurement and Management, Princeton University Press.

Drazen, A., Bartolini, L. [1997] - "When Liberal Policies Reflect External Shocks, What Do We Learn?", Journal of International Economics, Vol. 42, nº 3-4, May.

Edwards, S. [1999] - “How Effective are Capital Controls?”, NBER WP \#7413.

Edwards,S. , Valdés, R. e De Gregorio, J. [2000] - "Controls on Capital Inflows: Do They Work?", NBER, WP \#7645.

Eichengreen, B. , Tobin, J. , Wyplosz, C. [1995] - "Two Cases for Sand in the Wheels of International Finance", The Economic Journal, 105 (January), 162-172.

Eichengreen, B. [1999] - "Toward a New International Financial Architecture: A Practical Post-Asia Agenda", Institute for International Economics.

Eichengreen, B., Leblang, D. [2002] - "Capital Account Liberalization and Growth: Was Mr. Mahathir Right?”, NBER Working Paper \# 9427.

Fischer, S. [2002] - "Financial Crises and Reform of the International Financial System”, NBER, WP \# 9297.

Forbes, K. [2003a] - "One Cost of the Chilean Capital Controls: Increased Financial Constraints for Smaller Trade Firms", NBER WP \# 9777.

Forbes, K. [2003b] - "Capital Controls: Mud in the Wheels of Market Discipline", paper presented at a conference, http://web.mit.edu/kjforbes/www.

Franco, G. [2000] - "The Real Plan and the Exchange Rate", Essays in International Finance, No. 217, Princeton University.

Franco, G. , Pinho Neto, D. [2004] - "A desregulação da conta de capitais: limitações macroeconômicas e regulatórias”, PUC-Rio, WP \#479.

Frankel, J. , Rose, A. [1996] - "Currency Crashes in Emerging Markets: An Empirical Treatment", Journal of International Economics, November 1996, 351-366.

Frankel, Jeffrey A. [1991] - "Quantifying International Capital Mobility in the 1980's". In Bernheim, B. D. and Shoven, J. B., eds., National Saving and Economic Performance, National Bureau of Economic Research, The University of Chicago Press, 
Chicago.

Garber, P. [1998] - "Derivatives in International Capital Flow", NBER Working Paper \# 6623.

Garcia, M. , Barcinski, A. [1998] - "Capital Flows to Brazil in the Nineties: Macroeconomic Aspects and the Effectiveness of Capital Controls", The Quaterly Review of Economics and Finance, Vol.38, No.3, Fall 1998, 319-357.

Garcia, M. , Valpassos, M. [2000] - "Capital Flows, Capital Controls and Currency Crisis: The Case of Brazil in the Nineties", in Larraín, F. (Editor), Capital Flows, Capital Controls and Currency Crises. Latin America in the 1990's, University of Michigan.

Garcia, M. e Olivares, G. [2001] - "O Prêmio de Risco da Taxa de Câmbio no Brasil durante o Plano Real”, Revista Brasileira de Economia, January.

Garcia, M. and Didier, T. [2003], "Very High Interest Rates and the Cousin Risks: Brazil During the Real Plan" in José González e Anne O. Krueger, eds., Macroeconomic Reforms: The Second Generation, The University of Chicago Press

Glick, R. and Hutchinson, M. [2004] - "Capital Controls and Exchange Rate Instability in Developing Economies", Journal of International Money and Finance.

Goldfajn, I. e Minella [2005] - "Capital flows and controls in Brazil: what have we learned?", NBER WP \#11640.

Goldstein, M. [1995] - "Coping with Too Much of a Good Thing: Policy Responses for Large Capital Inflows to Developing Countries", Institute for International Economics.

Ito, T. , Portes, R. [1998] - "Dealing with Asian Financial Crises", European Economic Perspectives, CERP.

Keynes, J. M. [1936] - “The General Theory of Employment, Interest and Money”.

Obstfeld, M. [1994] - “The Logic of Currency Crises”, NBER WP \# 4640.

Nadal-de-Simone, F. e Sorsa, P. [1999] - "A Review of Capital Account Restrictions in Chile in the 1990's" IMF Working Paper \# WP/99/52.

Neely, C. [1999] - "An Introduction to Capital Controls", Review - Federal Reserve Bank of St. Louis”, November/December 1999.

Rajan, R. [2005] - "Has Financial Development Made the World Riskier?", NBER WP \#11728.

Reinhart, C. , Todd Smith, R. [2001] - "Temporary Controls on Capital Inflows", NBER WP \#8422.

Reinhart, C., Edison, H. [1999] - “Stopping Hot Money”, NBER Conference. 
Rogoff, K. [1999] - "International Institutions for Reducing Global Financial Instability", Journal of Economic Perspectives - Vol. 13, No. 4, Fall 1999, 21-42.

Stiglitz, J. [1999] - "Bleak Growth Prospects for the Developing World", International Herald Tribune, April 10-11, p.6.

Tobin, J. 1978 - "A Proposal for International Monetary Reform”, Eastern Economic Journal, Vol. 4 (July-October), pp. 15359.

Valdes-Prieto,S. e Soto, M. [2000] - "Selective Capital Controls: Theory and Evidence" em Larraín, F. (Editor), Capital Flows, Capital Controls and Currency Crises. Latin America in the 1990's, University of Michigan.

\section{VII - APPENDIX: Others circumvention methods}

\section{CASE 9: Privatization Currency}

Another loophole in Brazil's capital control legislation between 1993 and 1995 was that it granted permission for funds investing in the country's privatization to use Annex IV for investing in National Treasury Notes (NTNs). Initial legislation sought to encourage inflows of foreign capital directed at investments in privatization, but the market began establishing short term fixed income investments as privatization investments, thereby capturing the tax benefits of investing in Brazil's domestic debt through Annex IV. This method of capital controls avoidance seemed to be widely employed. One indication is that the flow for privatization via Annex IV between April and July of 1993 averaged US\$4.36 millions. In August of 1993, a capital control was applied that prohibited fixed income investments via Annex IV and permitted only investing through specific fixed income funds that were subject to a 5\% IOF tax. In September of 1993, the flow declared as privatization resources rose to US\$176 millions. This means that when fixed income investments were restricted, the flow declared as destined for privatization increased more than $3000 \%$ in less than two months.

\section{CASE 10: Resolution 63 “CAIPIRA”(“Country 63”)}

Another strategy for raising foreign funds with tax benefits was provided for by Central Bank of Brazil Resolution No. 63 for agriculture financing. The operation was similar to those involving ACCs. Rural producers were permitted to borrow abroad, with tax benefits, and began selling them to financial investors, so that short term loans declaring agricultural destinations were a common market practice. The loan, however, was redirected to financial market transactions.

In general, the cost of these loans was also less than the CDI. This meant that the same strategy undertook with ACCs could be replicated with the "63 Caipira," that is, raising funds at a cost well below the CDI and investing the money in the overnight market or in margin deposits required by the BM\&F interest derivatives. The capital that in theory was for agriculture investments was actually redirected to short term fixed 
income investments. The transaction was strictly within legal boundaries, because rural producers officially took out the loans.

Through this "63 Caipira" strategy, investors raised funds at short term rates to perform the "carry-trade". At the same time, investors with foreign capital could use this channel to invest in fixed income given the ease with which it was redirected to the financial market. This legislation loophole meant gains for both the borrower and the lender.

Only in 1996 did the Central Bank limit transactions using Resolution 63. The institution's 1996 Report clarified:

"In order to avoid the application of resources from long term loans in speculative investments, Circular No. 2.660, of 2.8.96, limited the alternatives for investing funds raised under Resolution 63 when not used by their final borrower."

The next case of circumvention involves a loophole in legislation that permitted investments in debentures under Annex IV. Prices of some of the debentures were linked to Brazil's benchmark interest rate, opening a door for bypassing restrictions on fixed income investments.

CASE 11: Siderbrás debentures, and others.

One method for avoid the restriction on fixed income investments with tax benefits provided for by Annex IV was to take advantage of the loophole in legislation that permitted investing in debentures through this channel. Between August 1993 and November 1993, this loophole allowed investors to earn the returns of fixed income by investing in debentures that were linked to the base interest rate. One example involved the debentures of the company Siderbrás.

In August of 1993, the volume of debenture investments under Annex IV was US\$ 275 million, or 4\% of the total Annex IV Portfolio in the country. In September, after the capital control was introduced, this amount jumped to US\$ 1.3 billion, and in November of 1993 reached its highest to date at US\$3 billion, or 34\% of the portfolio. In November of 1993, the government prohibited debenture investments using Annex IV, closing the door on this form of circumvention.

In this section's conclusion, we exhibit a table with the composition of the total Annex IV Portfolio in the country, and we analyzed, as in Garcia \& Barcinski [1998], the dynamic of flow shifts among items in Annex IV prompted by capital controls.

The cost of bypassing controls by investing in debentures, the $\tau^{*}$, was zero, because the yield of these debt instruments was tied to the interest rates sought by investors, and moreover offered the tax benefits of Annex IV investments. 